\title{
Angiostatic, tumor inflammatory and anti-tumor effects of CXCL4 47-70 and CXCL4L147-70 in an EGF-dependent breast cancer model
}

\author{
Katrien Van Raemdonck ${ }^{1}$, Nele Berghmans ${ }^{1}$, Vincent Vanheule ${ }^{1}$, Antonella Bugatti ${ }^{2}$, \\ Paul Proost ${ }^{1}$, Ghislain Opdenakker ${ }^{3}$, Marco Presta ${ }^{2}$, Jo Van Damme ${ }^{1}$, Sofie Struyf ${ }^{1}$ \\ ${ }^{1}$ Laboratory of Molecular Immunology, KU Leuven - University of Leuven, Department of Microbiology and Immunology, Rega \\ Institute for Medical Research, Leuven, Belgium \\ ${ }^{2}$ Laboratory of Experimental Oncology and Immunology, University of Brescia, Department of Molecular and Translational \\ Medicine Brescia, Italy \\ ${ }^{3}$ Laboratory of Immunobiology, KU Leuven - University of Leuven, Department of Microbiology and Immunology, Rega \\ Institute for Medical Research, Leuven, Belgium
}

Correspondence to:

Sofie Struyf, e-mail: Sofie.Struyf@rega.kuleuven.be

Key words: chemokines, CXCL4, CXCL4L1, EGF, CCL5, angiogenesis

Received: June 12, $2014 \quad$ Accepted: September 29, $2014 \quad$ Published: October 21, 2014

\section{ABSTRACT}

CXCL4 and CXCL4L1, platelet-derived CXC chemokines, and their carboxy-terminal peptides CXCL4 ${ }^{47-70}$ and CXCL4L1 ${ }^{47-70}$ previously displayed angiostatic and anti-tumoral activity in a melanoma model. Here, we found CXCL4 ${ }^{47-70}$ and CXCL4L1 ${ }^{47-70}$ to inhibit lymphatic endothelial cell proliferation in vitro. Furthermore, the angiostatic potential of CXCL4 ${ }^{47-70}$ and CXCL4L1 ${ }^{47-70}$ was tested against different angiogenic stimuli (FGF1, FGF2, FGF8, EGF and VEGF). Besides reducing FGF2-induced vascular endothelial cell growth, CXCL4 ${ }^{47-70}$ and CXCL4L1 ${ }^{47-70}$ efficiently counteracted EGF. Consequently, we considered their anti-tumoral potential in EGF-dependent MDA-MB-231 breast tumors. In tumor-bearing mice, $\mathrm{CXCL4}^{47-70}$ reduced tumor growth better than $\mathrm{CXCL4L1}^{47-70}$. In CXCL4 ${ }^{47-70}$-treated tumors significantly more intratumoral monocytes/macrophages and dendritic cells were present and higher expression levels of CCL5 and IFN-y were detected by qPCR on tumor lysates. Because neither peptide was able to specifically bind CXCR3A or CXCR3B, differential glycosaminoglycan binding and direct interaction with cytokines (EGF and CCL5) might explain any differences in anti-tumoral effects. Notably, CCL5-induced monocyte chemotaxis in vitro was increased by addition of CXCL4 ${ }^{47-70}$ or CXCL4L1 ${ }^{47-70}$. Finally, CXCL4 ${ }^{47-70}$ and CXCL4L1 ${ }^{47-70}$ inhibited proliferation of MDA-MB-231 cells. Our results suggest a tumor type-dependent responsiveness to either $\mathrm{CXCL4}^{47-70}$ or CXCL4L1 ${ }^{47-70}$ treatment, defined by anti-proliferative, angiostatic and inflammatory actions, and substantiate their therapeutic potential.

\section{INTRODUCTION}

Angiogenesis, the formation of an ever more branching network of blood vessels from a pre-existing vascular network, has been established as a requisite for successful tumor growth and cancer progression $[1,2]$. Anti-angiogenic therapy thus offers a promising approach to tackle one of the leading causes of mortality worldwide. However, classic anti-angiogenic therapeutics have encountered important hurdles and interest in less obvious targets, including inflammatory mediators such as the chemokines, increases [3-7]. These chemotactic cytokines play an important role in immunity as they control activation and migration of particular subsets of leukocytes. Chemokines have been implicated though in a variety of other biological processes, including angiogenesis $[8,9]$. A distinction should be made between angiogenic (mostly CC and ELR-positive CXC chemokines) and angiostatic chemokines (mostly ELRnegative CXC chemokines). The latter group comprises the CXCR3 ligands, namely CXCL9/Monokine induced by interferon- $\gamma$ (Mig), CXCL10/Interferon- $\gamma$-induced protein 10 (IP-10), CXCL11/Interferon-inducible T-cell $\alpha$ chemoattractant (I-TAC), CXCL4/Platelet factor-4 (PF-4) 
and CXCL4L1/PF-4variant. These CXCR3 ligands inhibit endothelial cell proliferation and migration, favoring the delicate angiogenic balance to shift towards angiostasis $[10,11]$. In keeping with a long line of research within our group, the focus of this study lies with the platelet products CXCL4 and CXCL4L1. These non-allelic variants are both secreted by activated platelets as 70 amino acid-long mature proteins, differing only in 3 residues situated near the carboxy-terminal end $\left(\mathrm{Pro}^{58} \rightarrow \mathrm{Leu}^{58}\right.$, $\mathrm{Lys}^{66} \rightarrow \mathrm{Glu}^{66}, \mathrm{Leu}^{67} \rightarrow \mathrm{His}^{67}$ for CXCL4 $\rightarrow$ CXCL4L1) [12]. Despite the limited amino acid substitutions, the extent to which these affect protein structure, and subsequently biological function, is remarkable. As a single replacement, the shift from leucine on position 67 in CXCL4 to histidine in CXCL4L1 causes the carboxyterminal helix to protrude into the aqueous space thereby exposing the entire helix [13]. This unique carboxyterminal 3D-structure of CXCL4L1 correlates with a decrease in glycosaminoglycan (GAG) affinity and a more outspoken angiostatic potential [13]. CXCL4L1 was demonstrated to inhibit both CXCL8- and basic fibroblast growth factor (FGF2)-induced endothelial cell chemotaxis more efficiently than CXCL4. However, CXCL4L1 is less likely to form heterodimers or compete for GAG binding [14-16]. Interestingly, carboxy-terminal peptides of both CXCL4 and CXCL4L1 have been illustrated to preserve the angiostatic and anti-tumoral potential [17-19]. CXCL4- and CXCL4L1-derived peptides are excellent probes to unravel the working mechanism of these angiostatic chemokines. A better understanding could benefit future therapeutic use of CXCL4, CXCL4L1 or their derived peptides. Here, we further explored the qualities of the carboxy-terminal peptides CXCL4 ${ }^{47-70}$ and CXCL4L $1^{47-70}$ as anti-tumoral agents, more specifically against a human epidermal growth factor (EGF)-dependent tumor cell line, MDA-MB-231. Our in vitro data support the hypothesis that both CXCL4 ${ }^{47-70}$ and CXCL4L1 ${ }^{47-70}$ retain their angiostatic potential. Both peptides were shown to inhibit proliferation of microvascular endothelial cells, including lymphatic endothelial cells. We also demonstrated MDA-MB-231 tumor cells to be sensitive to the anti-proliferative effect of CXCL4 ${ }^{47-70}$ and CXCL4L1 $1^{47-70}$ in vitro. Surprisingly, mostly CXCL4 ${ }^{47-70}$ exerted an anti-tumoral effect on EGF-dependent MDAMB-231 tumor growth in vivo.

\section{RESULTS}

\section{Anti-proliferative effect of CXCL4 $4^{47-70}$ and CXCL4L1 17-70 on mitogen-stimulated bovine endothelial cells}

Vandercappellen et al. demonstrated the anti-tumoral effects of carboxy-terminal peptides derived from CXCL4 and CXCL4L1 and illustrated that both CXCL4 ${ }^{47-70}$ and CXCL4L1 1 47-70 retained the ability to block FGF2-induced endothelial cell motility and proliferation [19]. We investigated whether CXCL4 $4^{47-70}$ and CXCL4L1 ${ }^{47-70}$ counteracted other growth factors with similar efficiency. A screening was performed on bovine aortic endothelial cells (GM7373) as shown in Figure 1A. Consistent with previous work [19], both CXCL4 ${ }^{47-70}$ and CXCL4L1 ${ }^{47-70}(0.4 \mu \mathrm{g} / \mathrm{ml})$ reduced FGF2-induced GM7373 proliferation to $28 \pm 10 \%$ and $47 \pm 4 \%$, respectively. The peptides' effect on epidermal growth factor (EGF) stimulation also stood out as CXCL4 ${ }^{47-70}$ reduced GM7373 proliferation to $74 \pm 3 \%$. Remarkably, CXCL4L1 ${ }^{47-70}$ consistently inhibited EGF's mitogenic activity more efficiently, lowering EGF-stimulated proliferation to $49 \pm 1 \%$.

\section{$\mathrm{CXCL4}^{47-70}$ and CXCL4L11 ${ }^{47-70}$ inhibit human endothelial cell proliferation}

Our preliminary proliferation screenings suggested angiogenic EGF stimulation to be particularly sensitive to addition of CXCL4L1 ${ }^{47-70}$. Interestingly, EGF does not rely on glycosaminoglycans (GAG) as co-receptors to exert its activity. Furthermore, though intact CXCL4 has been reported to counteract this growth factor, its mode of action has yet to be fully unraveled [20]. We examined proliferation of human retinal microvascular endothelial cells (HMVEC) when stimulated with EGF as opposed to a combination of EGF and CXCL4 $4^{47-70}$ or CXCL4L1 ${ }^{47-70}$ (Figure 1B). As expected, EGF (3 ng/ml) stimulated HMVEC proliferation in an MTT assay with a proliferation index $(\mathrm{PI})$ of $1.42 \pm 0.08(\mathrm{n}=7)$. Further addition of $\mathrm{CXCL}^{47-70}$ caused the PI to drop dose-dependently $(\mathrm{PI}=1.13 \pm 0.07, \mathrm{p}=0.015, \mathrm{n}=7 ; \mathrm{PI}=0.96 \pm 0.06, \mathrm{p}=0.003, \mathrm{n}=7$; $\mathrm{PI}=0.93 \pm 0.07, \mathrm{p}=0.008, \mathrm{n}=6$ at $0.3,1$ and $3 \mu \mathrm{g} / \mathrm{ml}$, respectively). Similarly, CXCL4L1 $1^{47-70}$ also significantly reduced EGF-induced proliferation $(\mathrm{PI}=1.17 \pm 0.06$, $\mathrm{p}=0.041 ; \mathrm{PI}=1.05 \pm 0.07, \mathrm{p}=0.015 ; \mathrm{PI}=0.98 \pm 0.13, \mathrm{p}=0.041$ at $0.3,1$ and $3 \mu \mathrm{g} / \mathrm{ml}$, respectively; $\mathrm{n}=7$ ).

As single stimulus (without growth factor stimulation) CXCL4 ${ }^{47-70}$ and CXCL4L1 ${ }^{47-70}$ significantly reduced baseline proliferation (Figure 1C). CXCL4 ${ }^{47-70}$ reduced proliferation to a PI of $0.77 \pm 0.08(\mathrm{p}=0.011$, $\mathrm{n}=8)$ and $0.59 \pm 0.09(\mathrm{p}=0.001, \mathrm{n}=6)$ at $1 \mu \mathrm{g} / \mathrm{ml}$ and $3 \mu \mathrm{g} / \mathrm{ml}$, respectively. Similarly, the PI was lowered to $0.86 \pm 0.12(\mathrm{p}=0.043, \mathrm{n}=8)$ and $0.70 \pm 0.09(\mathrm{p}=0.009$, $\mathrm{n}=7$ ) after stimulation with the variant CXCL4L1 ${ }^{47-70}$ at $1 \mu \mathrm{g} / \mathrm{ml}$ and $3 \mu \mathrm{g} / \mathrm{ml}$, respectively. The effect of CXCL4 ${ }^{47-70}$ on constitutive HMVEC proliferation was more prominent than that of CXCL4L1 $1^{47-70}$.

\section{$\mathrm{CXCL4}^{47-70}$ and CXCL4L1 ${ }^{47-70}$ induce cell cycle arrest in HMVEC}

Previously, the EGF-induced reduction of the cyclin-dependent kinase inhibitor p21 was described [20]. Interestingly, CXCL4 appeared to interfere with this 

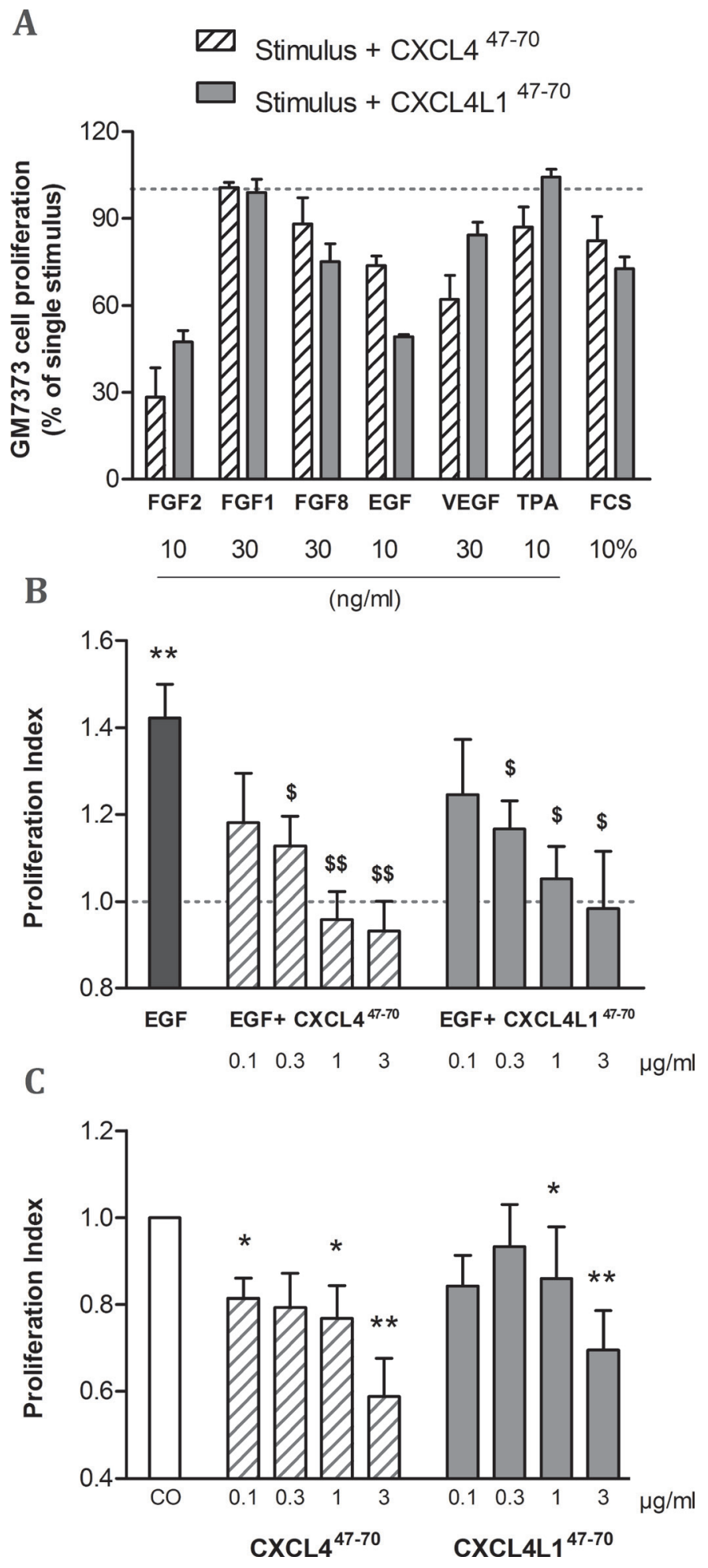

Figure 1: Effects of CXCL4 $4^{47-70}$ and CXCL4L1 $1^{47-70}$ on endothelial cell proliferation. Firstly, bovine aortic endothelial GM7373 cells were incubated with a range of mitogenic stimuli either in the presence or absence of CXCL447-70 or CXCL4L147-70 (both $0.4 \mu \mathrm{g} / \mathrm{ml}$ ) for $24 \mathrm{~h}(\mathbf{A})$. Cell counts after incubation with one of the carboxy-terminal peptides were expressed as percentages (mean \pm s.e.m.), relative to cell counts after stimulation with the indicated mitogenic stimulus alone (100\%; dotted line). As only 3 independent experiments were included in this preliminary screening, no statistical significance was reached. HMVEC were stimulated with either control medium (CO), CXCL4 ${ }^{47-70}$ or CXCL4L1 17-70 (both 0.1 to $3 \mu \mathrm{g} / \mathrm{ml}$ ), combined with $3 \mathrm{ng} / \mathrm{ml} \mathrm{EGF} \mathrm{(B)} \mathrm{or} \mathrm{as} \mathrm{single} \mathrm{stimuli} \mathrm{(C)} \mathrm{over} \mathrm{the}$ course of 3 to 4 days. Afterwards plates were developed according to MTT assay protocol. Optical density was determined at $570 \mathrm{~nm}$ and $630 \mathrm{~nm}$. The proliferation index in condition $\mathrm{X}$ (mean \pm s.e.m.) represents the ratio of the calculated $\Delta \mathrm{OD} 570-630_{\mathrm{x}}$ over $\Delta \mathrm{OD} 570-630_{\mathrm{CO}}$, in which control treatment serves as an internal reference ( $\mathrm{PI}=1$; dotted line). $\mathrm{A}: \mathrm{n}=3$; $\mathrm{B}$ and $\mathrm{C}: \mathrm{n}=6$ to $7 ;{ }^{*} \mathrm{p}<0.05,{ }^{* *} \mathrm{p}<0.01$ (versus $\mathrm{CO}$ ); $\$ \mathrm{p}<0.05, \$ \$ \mathrm{p}<0.01$ (versus $\mathrm{EGF}$ ) 
p21 downregulation in EGF-stimulated endothelial cells. Therefore, we studied the effects of chemokine-derived peptides on p21 levels and, with it, their ability to arrest the cell cycle. Evaluation of the p21 content in HMVEC did confirm CXCL4 $4^{47-70}$ and CXCL4L1 $1^{47-70}$ to counteract the tendency of EGF to reduce p21 (Figure 2). EGF (20 ng/ml) reduced intracellular $\mathrm{p} 21$ to $75.82 \pm 3.69 \%(n=9 ; \mathrm{p}<0.001)$ compared to control-treated levels. Addition of the peptides in combination with EGF restored p21 levels to control levels (i.e. p21 levels in the cells treated with peptide plus EGF were not statistically different from buffer-treated cells). After adding 1, 3 or $10 \mu \mathrm{g} / \mathrm{ml} \mathrm{CXCL4}{ }^{47-70}$, p21 levels were also significantly higher than those in HMVEC stimulated solely with $20 \mathrm{ng} / \mathrm{ml}$ EGF $(106.90 \pm 15.12 \%$, $\mathrm{p}=0.039, \mathrm{n}=6 ; 100.02 \pm 8.67 \%, \mathrm{p}=0.039, \mathrm{n}=9$; and 125.51 $\pm 15.05 \%, p=0.005, n=5$, respectively). Stimulation with

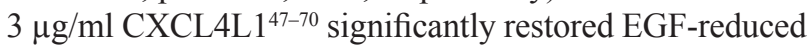
p21 levels to $115.06 \pm 17.41 \%(p=0.033, n=5)$.

\section{$\mathrm{CXCL4}^{47-70}$ and CXCL4L1 ${ }^{47-70}$ reduce lymphatic endothelial cell proliferation}

Only recently, the link between the angiostatic CXCR3 ligands and lymphangiogenesis was recognized [21-23]. As the lymphatic vasculature has been implied to be an escape route for metastatic tumor cells, its blockade offers an interesting new therapeutic perspective [24]. Though proliferation of human dermal lymphatic microvascular endothelial cells (HLEC) was not responsive to EGF-stimulation (data not shown), baseline proliferation was indeed sensitive to CXCL4 ${ }^{47-70}$ and CXCL4L1 ${ }^{47-70}$ (Figure 3). CXCL4 ${ }^{47-70}$ reduced the PI to $0.70 \pm 0.06(\mathrm{p}=0.030), 0.69 \pm 0.06(\mathrm{p}=0.030)$ and 0.37 $\pm 0.04(\mathrm{p}=0.030)$ at $0.3,1$ and $3 \mu \mathrm{g} / \mathrm{ml}$, respectively $(n=4)$. The variant peptide CXCL4L $1^{47-70}$ reduced the PI less efficiently to $0.90 \pm 0.05(\mathrm{p}=0.312, \mathrm{n}=4), 0.82 \pm 0.05$ and $0.66 \pm 0.04$ (both $\mathrm{p}=0.030, \mathrm{n}=4$ ) at $0.3,1$ and $3 \mu \mathrm{g} / \mathrm{ml}$, respectively.

\section{$\mathrm{CXCL4}^{47-70}$ and CXCL4L1 ${ }^{47-70}$ reduce proliferation of MDA-MB-231 cells}

While most of the anti-tumoral effects of CXCL4 and CXCL4L1 have been attributed to their angiostatic potential, little attention has been paid to the direct antiproliferative effect they may exert on malignant cells themselves [25]. We evaluated proliferation of MDAMB-231, EGF-dependent breast cancer cells lacking estrogen and progesterone receptor expression as well as human EGF-receptor 2 (HER2) amplification (triplenegative) $[26,27]$. Our results show that CXCL4 ${ }^{47-70}$ and CXCL4L $1^{47-70}$ were able to significantly and dosedependently reduce MDA-MB-231 proliferation (Figure 4). The PI was lowered to $0.87 \pm 0.04(\mathrm{p}=0.023, \mathrm{n}=7)$, $0.66 \pm 0.04(\mathrm{p}<0.001, \mathrm{n}=7)$ and $0.21 \pm 0.05(\mathrm{p}<0.001, \mathrm{n}=3)$ at $0.3,3$ and $10 \mu \mathrm{g} / \mathrm{ml}$ of $\mathrm{CXCL} 4^{47-70}$, respectively (all conditions tested in triplicate). This indicates that high doses of CXCL4 ${ }^{47-70}$ have a potent direct antiproliferative effect on MDA-MB-231 cells. Increasing doses of CXCL4L1 $1^{47-70}$ also reduced the PI to $0.78 \pm 0.04$, $0.76 \pm 0.08$ and $0.26 \pm 0.04(\mathrm{p}<0.001, \mathrm{n}=7$ at $3 \mu \mathrm{g} / \mathrm{ml}$; $\mathrm{p}=0.01, \mathrm{n}=7$ at $10 \mu \mathrm{g} / \mathrm{ml}$; and $\mathrm{p}<0.001, \mathrm{n}=3$ at $30 \mu \mathrm{g} / \mathrm{ml}$, respectively; tested in triplicate). We attempted to corroborate these data by assessment of the intracellular p21 content, yet found this p53-dependent signaling

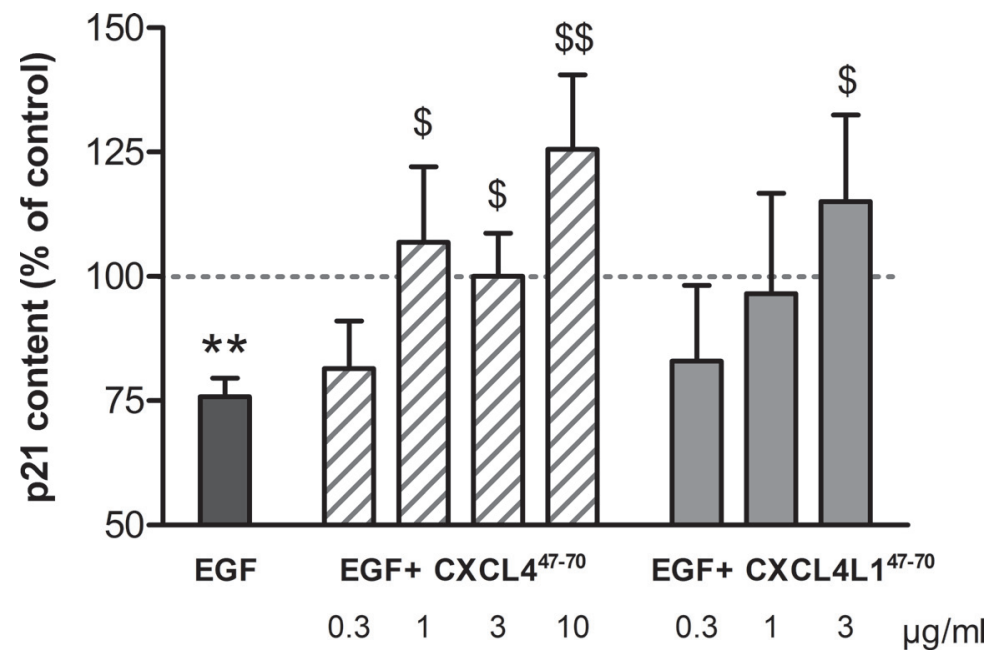

Figure 2: p21 content in HMVEC after CXCL4 ${ }^{47-70}$ and CXCL4L1 ${ }^{47-70}$ stimulation. The impact of CXCL4 ${ }^{47-70}$ and CXCL4L1 ${ }^{47-70}$ on the cell cycle in HMVEC was evaluated by quantification of p21 production. Intracellular p21 concentrations, known to drop upon EGF stimulation $(20 \mathrm{ng} / \mathrm{ml})$, were also evaluated in HMVEC stimulated with EGF combined with either CXCL4 ${ }^{47-70}$ (0.3 to $10 \mu \mathrm{g} / \mathrm{ml})$ or CXCL4L1 $1^{47-70}(0.3$ to $3 \mu \mathrm{g} / \mathrm{ml})$. The ratio of $\mathrm{p} 21$ : total protein content was calculated for cell lysates after $15 \mathrm{~h}$ incubation with various stimuli. Results (mean \pm s.e.m.) are expressed relative to the $\mathrm{p} 21$ content after control treatment (100\%; dotted line). $\mathrm{n}=4$ to 9 ; $* * \mathrm{p}<0.01$ (EGF versus $\mathrm{CO}$ ); $\$ \mathrm{p}<0.05, \$ \mathrm{p}<0.01$ (versus $\mathrm{EGF}$ ) 


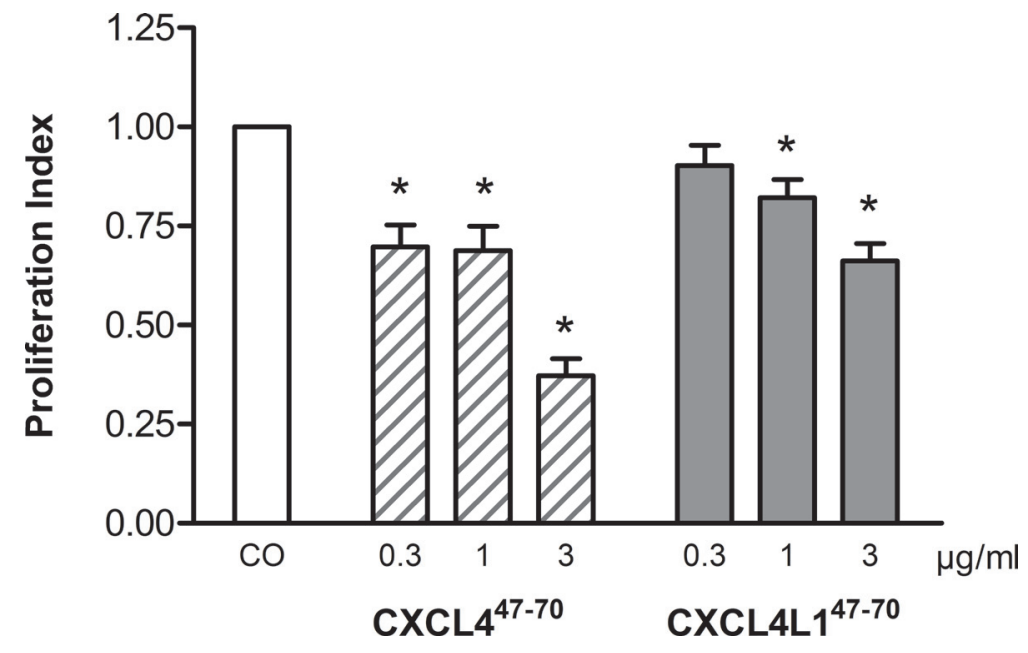

Figure 3: Effect of CXCL4 $4^{47-70}$ and CXCL4L1 $1^{47-70}$ on proliferation of lymphatic endothelial cells. In order to study proliferation of human lymphatic endothelial cells, HLEC were stimulated with either control medium treatment (CO), CXCL4 ${ }^{47-70}$ or CXCL4L1 ${ }^{47-70}$ (both 0.3 to $3 \mu \mathrm{g} / \mathrm{ml}$ ). After an incubation period of 3 to 4 days, cell cultures were analyzed with the MTT assay protocol. $\mathrm{n}=4 ;{ }^{*} \mathrm{p}<0.05$ (versus $\mathrm{CO}$ )

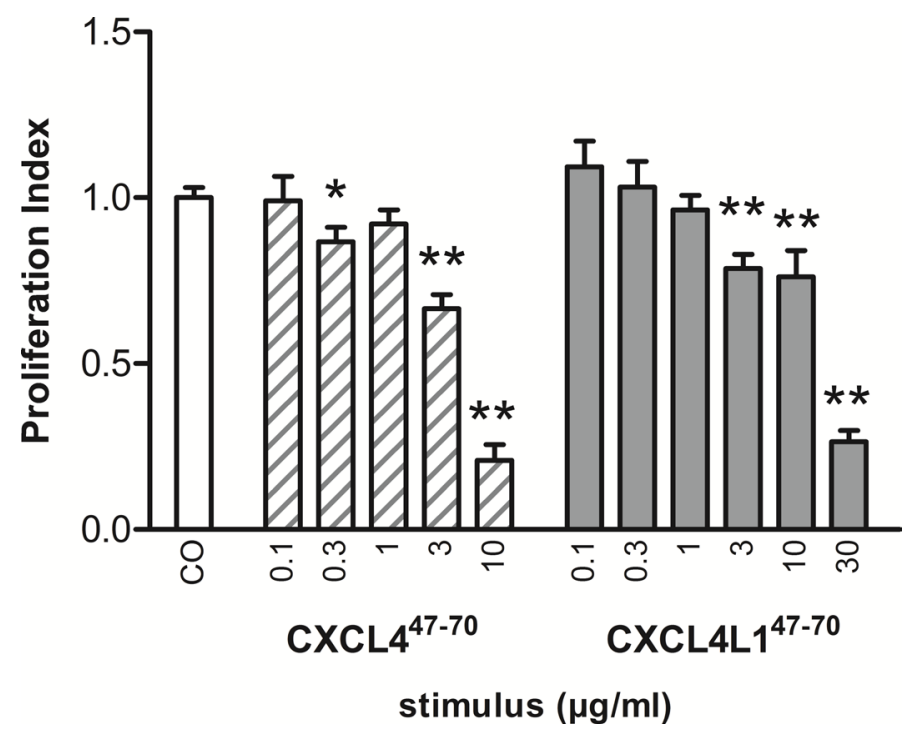

Figure 4: Proliferation of MDA-MB-231 cells examined after CXCL4 ${ }^{47-70}$ and CXCL4L1 ${ }^{47-70}$ stimulation. The antiproliferative effect of CXCL4 ${ }^{47-70}$ and CXCL4L1 $1^{47-70}$ on MDA-MB-231 tumor cells in vitro was investigated performing the MTT proliferation assay. Over the course of 3 to 4 days, MDA-MB-231 cells were incubated with either control treatment (CO), CXCL4 $47-70$ $(0.1$ to $10 \mu \mathrm{g} / \mathrm{ml})$ or CXCL4L1 $1^{47-70}(0.1$ to $30 \mu \mathrm{g} / \mathrm{ml})$. Afterwards cell cultures were analyzed with the MTT assay protocol. $\mathrm{n}=3$ to 7 , tested in triplicate per experiment; ${ }^{*} \mathrm{p}<0.05, * * \mathrm{p}<0.01$ (versus $\mathrm{CO}$ )

protein to fall below the detection limit of the available assays (data not shown) [28].

\section{$\mathrm{CXCL4}^{47-70}$ and CXCL4L1 ${ }^{47-70}$ reduce MDA-MB-231 tumor growth in vivo}

In order to evaluate the sum of their angiostatic and anti-tumoral effects, we assessed the in vivo relevance of intratumorally administered CXCL4 $4^{47-70}$ and CXCL4L1 ${ }^{47-70}$. Following up on s.c. MDA-MB-231 tumor growth through external examination (Figure 5), we noted a distinct reduction in tumor volume in CXCL4 $4^{47-70}$-treated versus vehicle-treated mice from 11 days after tumor cell inoculation onward $\left(24 \pm 6 \mathrm{~mm}^{3}\right.$ and $176 \pm 56 \mathrm{~mm}^{3}$, respectively; $\mathrm{p}<0.001$, both $\mathrm{n}=10$ ). At early stages up till around 20 days after tumor cell inoculation, the CXCL4L1 17-70-treated mice also displayed significantly smaller tumors than their vehicle-treated counterparts $\left(61 \pm 23 \mathrm{~mm}^{3}\right.$ on day $\left.11, \mathrm{p}=0.007, \mathrm{n}=10\right)$. However, after 25 days CXCL4L1 ${ }^{47-70}$ appeared less effective than 


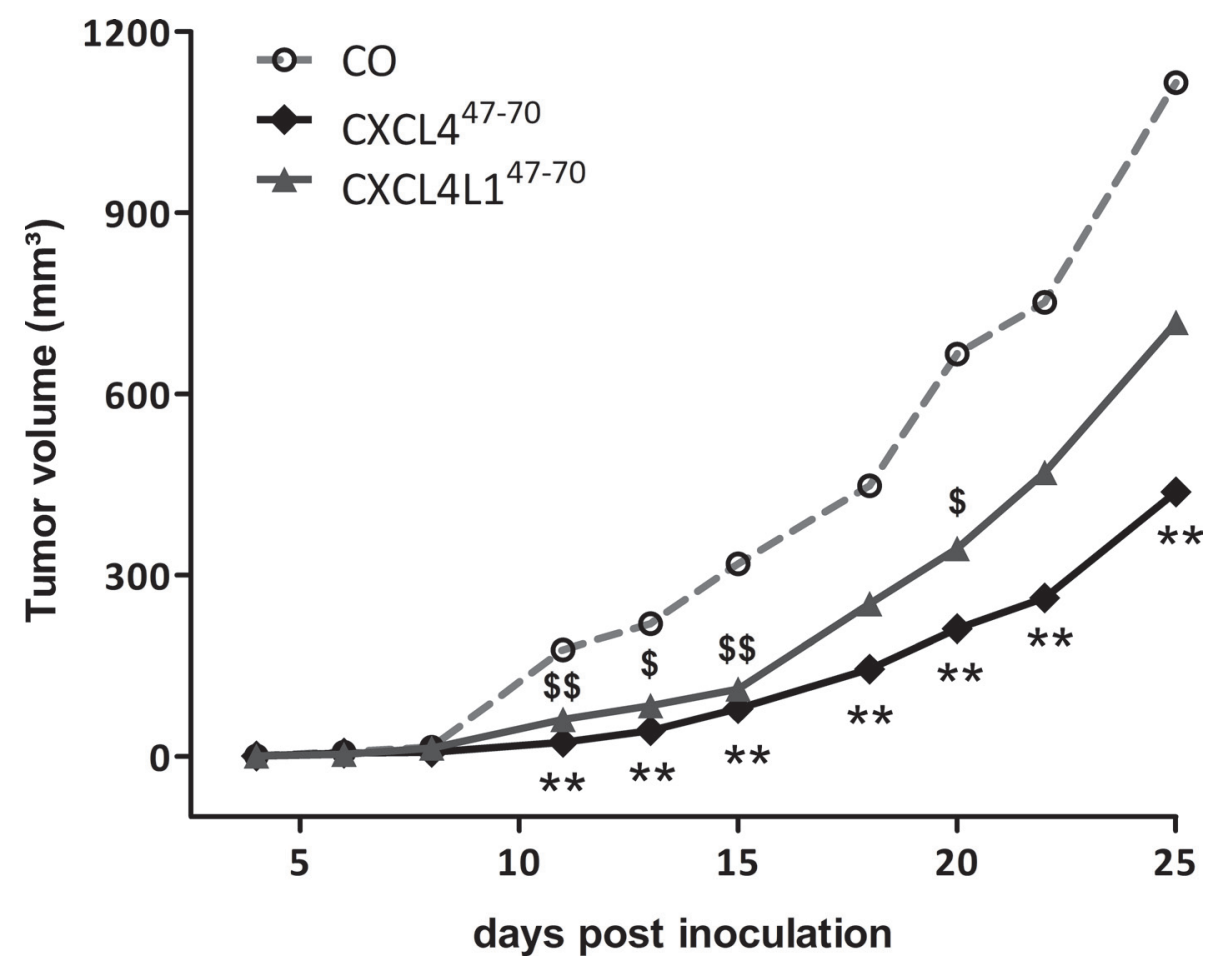

Figure 5: Tumor growth in CXCL4 $4^{47-70}$ - and CXCL4L1 ${ }^{47-70}$-treated tumor-bearing mice. Progressive tumor growth was assessed in SCID mice, subcutaneously inoculated with MDA-MB-231 tumor cells on day 0 and subsequently treated intratumorally with vehicle (CO), CXCL4 $4^{47-70}$ or CXCL4L1 ${ }^{47-70}(2.5 \mu \mathrm{g} ; 3 \times /$ week from day 3 onwards). The tumor volume was measured externally with calipers thrice a week and calculated using the formula $\left(4 \pi \mathrm{ab}^{2}\right) / 3$ in which a and $\mathrm{b}$ are the largest and smallest radius, respectively. Growth curves represent increasing mean tumor volumes. $\mathrm{n}=10$ /group; $* * \mathrm{p}<0.01$ (CXCL4 ${ }^{47-70}$ versus $\left.\mathrm{CO}\right) ; \$ \mathrm{p}<0.05, \$ \$ \mathrm{p}<0.01$ (CXCL4L1 $1^{47-70}$ versus $\left.\mathrm{CO}\right)$

$\mathrm{CXCL}^{47-70}$ in the treatment of MDA-MB-231 tumors. At day 25 , the mean tumor volume in the vehicle-treated mice amounted to $1116 \pm 149 \mathrm{~mm}^{3}$, whereas CXCL4 ${ }^{47-70}$ treatment had efficiently reduced tumor growth with a mean tumor volume of $438 \pm 97 \mathrm{~mm}^{3}(\mathrm{p}=0.002$, both groups $\mathrm{n}=10)$. The effect of CXCL4L1 ${ }^{47-70}$ was not statistically different from the control group $\left(719 \pm 153 \mathrm{~mm}^{3}, \mathrm{p}=0.121, \mathrm{n}=10\right)$.

Afterwards, 27 to 28 days after initial MDAMB-231 cell injection, masses and volumes of resected tumors were compared among the different treatment groups (Figure 6). Average tumor volume among vehicletreated animals amounted to $845 \pm 177 \mathrm{~mm}^{3}$, whereas after periodical intratumoral injection of CXCL4 ${ }^{47-70}$ average tumor volume was reduced to $308 \pm 61 \mathrm{~mm}^{3}$ $(p=0.001, n=10)$. Total tumor mass was also reduced from $1464 \pm 277$ to $523 \pm 108 \mathrm{mg}$ on average $(\mathrm{p}=0.002, \mathrm{n}=10)$. Administration of CXCL4L1 $1^{47-70}$ did not significantly alter tumor volume, nor mass $\left(647 \pm 161 \mathrm{~mm}^{3}, \mathrm{p}=0.256\right.$ and $953 \pm$ $208 \mathrm{mg}, \mathrm{p}=0.091$, respectively; both $\mathrm{n}=10$ ) after 4 weeks.

\section{Vascularization of CXCL4 $4^{47-70}$ - and CXCL4L1 ${ }^{47-70}$ treated tumors}

The impact of peptide treatment on the tumor vasculature was evaluated by quantification of immunohistochemically stained CD31-positive vessels.
However the angiostatic activity of neither $\mathrm{CXCL}^{47-70}$, nor CXCL4L1 ${ }^{47-70}$ was reflected by a reduced vascularization of the resected MDA-MB-231 tumors (data not shown). This inconsistency between our observations in vitro and in vivo evokes the question which alternative mechanisms may contribute to the anti-tumoral impact of peptide treatment as evidenced in the MDA-MB-231 tumor model.

\section{Tumor inflammation in CXCL4 $4^{47-70}$ - and CXCL4L1 ${ }^{47-70}$-treated MDA-MB-231 tumors}

Although the used SCID mice are characterized by defective T-lymphocyte development, monocyte, macrophage and NK cell populations have been shown to be unaffected in this mouse strain. We investigated possible changes in the immunological tumor microenvironment as a consequence of $\mathrm{CXCL}^{47-70}$ or CXCL4L1 ${ }^{47-70}$ treatment. Expression levels of various macrophage markers [29-31] were evaluated, all showing on average an elevated mRNA expression in the CXCL4 $4^{47-70}$-treated group (Figure 7). However, only F4/80 mRNA levels were significantly higher within resected tumors of CXCL4 ${ }^{47-70}$ treated mice compared to control mice $(p=0.008, n=10$; Figure 7A). These data indicate that intratumorally administered CXCL4 $4^{47-70}$ may favor local monocyte 

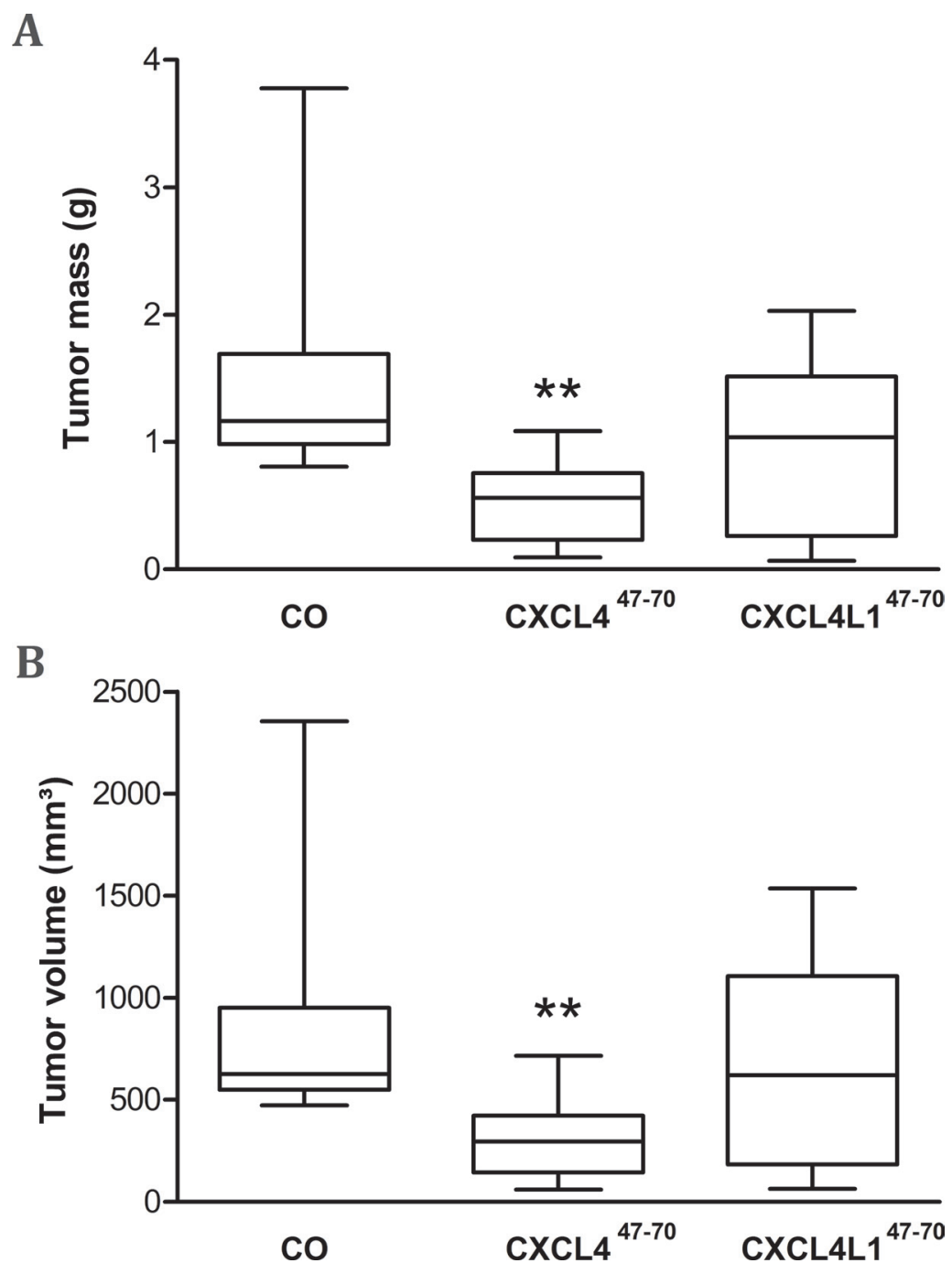

Figure 6: Tumor volume and mass after periodical CXCL4 ${ }^{47-70}$ and CXCL4L1 ${ }^{47-70}$ treatment. After vehicle (CO), CXCL4 ${ }^{47-70}$ or CXCL4L1 $1^{47-70}$ treatment $(2.5 \mu \mathrm{g} ; 3 \times /$ week $)$ of MDA-MB-231 tumor-bearing mice, on day 27 or 28 resected tumors were weighed (A) and tumor volumes (B) were determined ( $4 \pi \mathrm{abc} / 3$ in which a,b and c represent measured radii). Data were depicted as a 5-95 percentile Whiskers plot, in which the horizontal line marks the median value. $\mathrm{n}=10$ /group; $* * \mathrm{p}<0.01$

accumulation, as also evidenced by flow cytometric analysis (Co: $6.85 \pm 1.18 \% \mathrm{~F} 4 / 80^{+}$cells, $\mathrm{n}=10$; CXCL4 ${ }^{47-70}: 7.70 \pm 1.58 \% \mathrm{~F} 4 / 80^{+}$cells, $\mathrm{n}=9$ ). Overall, enhanced F4/80 mRNA levels indeed statistically correlated to an increased number of intratumoral $\mathrm{F} 4 / 80^{+}$ cells $(\mathrm{r}=0.322$ and $\mathrm{p}=0.011)$ (Figure 7B). Additionally, specific markers for M1 and M2 macrophage polarization were evaluated. TGM2 (Figure 7C) and CD204 (Figure 7D) are both specific markers of the pro-tumoral M2 phenotype, as opposed to F4/80 which is a general macrophage marker. These M2 markers exhibited only a modest increase after CXCL4 ${ }^{47-70}$ treatment. M1 markers IL-12 (Figure 7E) and NOS2 (Figure 7F) also only modestly increased after CXCL4 $4^{47-70}$ treatment, not reaching statistical significance. Nevertheless,
M1-related IL-12 upregulation seems more pronounced than that of TGM2 or CD204. Collectively, these observations suggest that the number of both M1 and M2 macrophages increases and that there is no dominance of a specific subtype. No significant changes in macrophage marker expression were observed in CXCL4L1 ${ }^{47-70}$ versus vehicle-treated mice. Flow cytometric analysis of the tumor stroma did, however, suggest that CXCL4L1 17-70 also recruited macrophages (CXCL4L1 $1^{47-70}$ : $7.74 \pm$ $1.35 \% \mathrm{~F} 4 / 80^{+}$cells, $\mathrm{n}=9$ ). In order to corroborate and further explore the inflammatory effect of our peptides, tumoral expression of the dendritic cell marker CD11c was evaluated (Figure 7G). CD11c mRNA was also more prominent in CXCL4 ${ }^{47-70}$-treated compared to vehicle-treated mice $(\mathrm{p}=0.032, \mathrm{n}=10)$. We additionally 
A

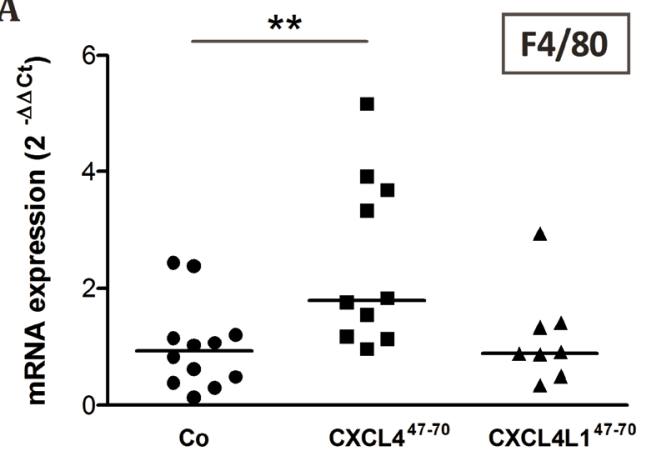

C

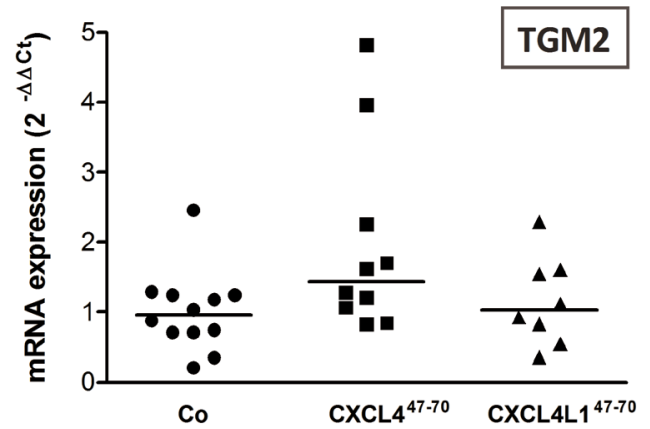

E

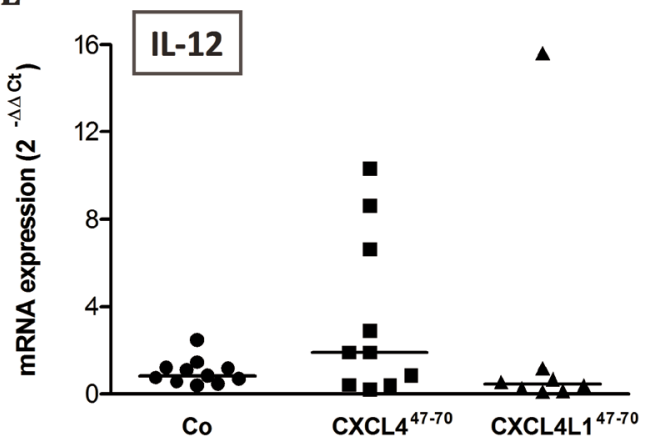

G

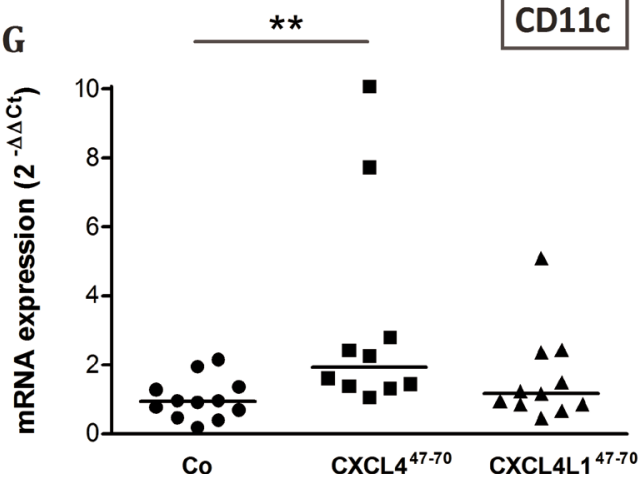

B

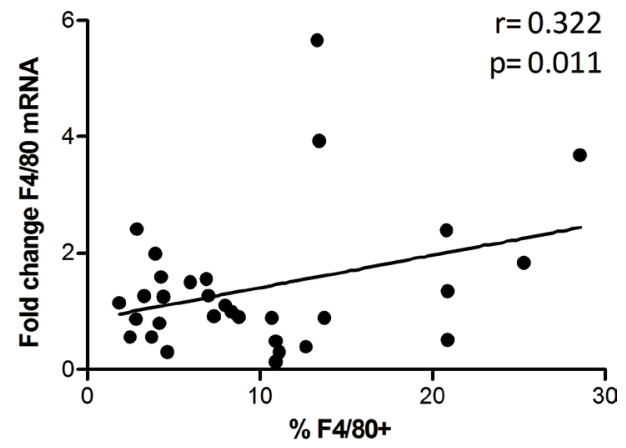

D

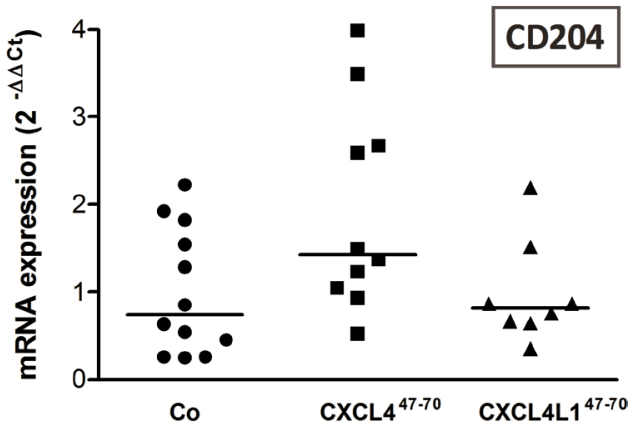

F
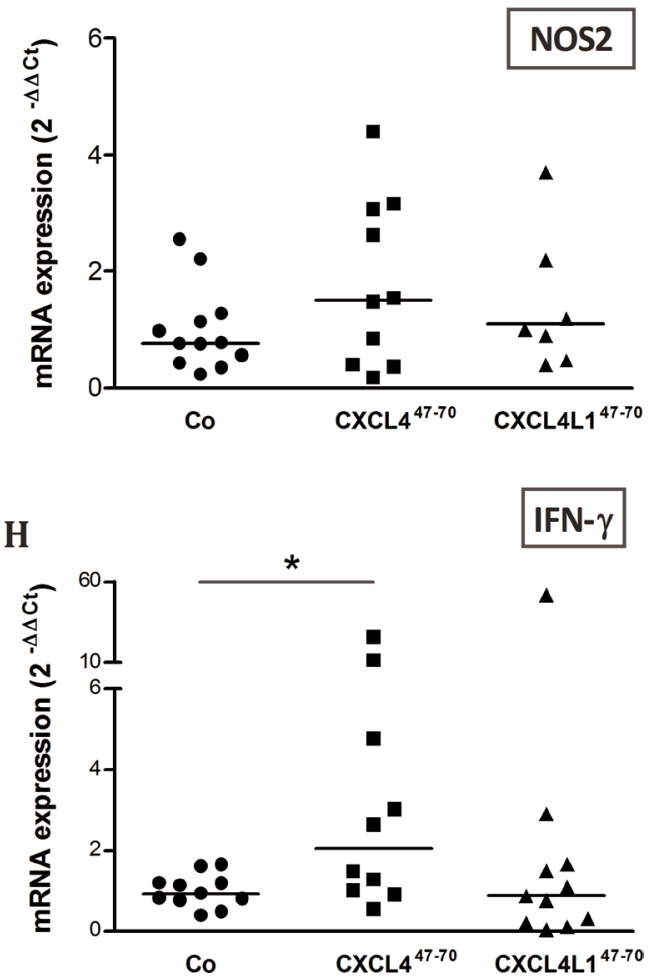

Figure 7: Effects of intratumoral CXCL4 ${ }^{47-70}$ and CXCL4L1 $1^{47-70}$ administration on the intratumoral inflammatory infiltrate. Relative expression of macrophage marker F4/80 was evaluated in vehicle (CO)-, CXCL447-70- and CXCL4L147-70-treated MDA-MB-231 tumors by qPCR (A). Additionally, the relative F4/80 mRNA levels were plotted in function of the percentage of $\mathrm{F} 4 / 80^{+}$cells as determined by flow cytometry (B). Panel B includes the calculated Pearson's correlation coefficient (r) and according p-value. In parallel, changes in the expression of M2 markers TGM2 and CD204 (C and D, respectively) and M1 markers IL-12 and NOS2 (E and F, respectively) were also analyzed by qPCR. Finally, expression of inflammatory markers CD11c (G) and IFN- $\gamma(\mathbf{H})$ were compared between groups. Fold changes in mRNA levels were calculated according the $2^{-\Delta \Lambda C T}$ method. The median value per group is indicated by a horizontal bar. ${ }^{*} \mathrm{p}<0.05,{ }^{* *} \mathrm{p}<0.01$ 
evaluated intratumoral expression of interferon- $\gamma$ (IFN- $\gamma$ ). This cytokine could promote endogenous expression of the CXCR3 ligands CXCL9, CXCL10 and CXCL11, which in turn are anti-tumoral, angiostatic chemokines [11]. As shown in Figure $7 \mathrm{H}$, IFN- $\gamma$ mRNA was most prominent following $\mathrm{CXCL} 4^{47-70}$ treatment. The significantly elevated expression of the inflammatory cytokine IFN- $\gamma$ possibly promotes anti-tumoral immunity (cytotoxicity, phagocytosis) thereby contributing to the anti-tumoral effect of CXCL4 $4^{47-70}$ in vivo.

\section{Cellular receptors of $\mathrm{CXCL} 4^{47-70}$ and CXCL4L1 ${ }^{47-70}$}

We further tried to reveal the mode of action of CXCL44 ${ }^{47-70}$ and CXCL4L1 $1^{47-70}$. First, we excluded that either peptide still binds/activates one of the CXCR3 isoforms, the receptors for intact CXCL4 and CXCL4L1. We performed binding assays using 3 to $3000 \mathrm{ng} / \mathrm{ml}$ of $\mathrm{NH}_{2}$-terminally biotinylated peptides and could not detect specific binding to transfected $\mathrm{CHO} / \mathrm{CXCR} 3 \mathrm{~A}$, nor $\mathrm{CHO} / \mathrm{CXCR} 3 \mathrm{~B}$ cells by flow cytometric analysis (data not shown). Nor could we detect any calcium signal in CXCR3A-transfectants after treatment with $2 \mu \mathrm{g} / \mathrm{ml}$ of CXCL4 $^{47-70}$ or CXCL4L1 17-70 (Supplemental Figure 1). Furthermore, neither peptide $(2 \mu \mathrm{g} / \mathrm{ml})$ was capable of inhibiting calcium signaling by intact CXCL10 $(5 \mathrm{ng} / \mathrm{ml})$, added to the cells as a second stimulus $100 \mathrm{~s}$ after addition of one of the peptides.

Next, we exploited surface plasmon resonance (SPR) analysis to assess the capacity of CXCL4 $4^{47-70}$ and CXCL4L1 $1^{47-70}$ to bind heparin immobilized to a BIAcore sensorchip, a model that mimics the binding of proteins to heparan sulphate proteoglycans associated to the cell surface [32]. When increasing concentrations of the two peptides were injected onto the heparin surface, sensorgram overlays (not shown) allowed the calculation of association $\left(K_{o n}\right)$ and dissociation $\left(K_{o f f}\right)$ rates and of $K_{d}$ (as $K_{\text {off }} / K_{\text {on }}$ ratio, Table 1$)$. Also, equilibrium binding data were used to generate the saturation curves shown in Figure $8 \mathrm{~A}$ and used to calculate a $K_{d}$ value independently from kinetic parameters (Table 1). Together, the data indicate that CXCL4 ${ }^{47-70}$ binds to immobilized heparin with high affinity $\left(K_{d}=16-72 \mathrm{nM}\right)$ whereas CXCL4L1 ${ }^{47-70}$ showed a very limited ability to bind the immobilized glycosaminoglycan $\left(K_{d}=1000-1200 \mathrm{nM}\right)$.

We could confirm the results from the SPR analysis in an alternative GAG binding assay performed in microtiter plates coated with heparin (Figure 8B). Dilution series of biotinylated CXCL4 $4^{47-70}$ and CXCL4L1 $1^{47-70}$ were added to investigate heparin affinity. Also in this assay less biotinylated CXCL4L1 ${ }^{47-70}$ peptide bound to the heparin-coated plate compared to biotinylated CXCL4 ${ }^{47-70}$, indicative of either a lower affinity of CXCL4L $1^{47-70}$ for heparin or a different stoichiometry of interaction.

\section{Interaction of CXCL4 $4^{47-70}$ and CXCL4L1 $1^{47-70}$ with EGF and CCL5}

Following studies by Nesmelova et al. [33] and von Hundelshausen et al. [34], we explored whether $\mathrm{CXCL}^{47-70}$ or CXCL4L1 $1^{47-70}$ could also directly interact with other cytokines. In view of the role of EGF in the MDA-MB-231 breast tumor model, we first evaluated the ability of either peptide to bind to this growth factor (Figure 9). EGF heterodimerization assays revealed EGF to retain both CXCL4 $4^{47-70}$ and CXCL4L1 $1^{47-70}$ equally well in a dose-dependent manner. These findings may present a plausible explanation for the direct anti-proliferative effect of both peptides on the EGF-dependent MDA-MB-231 tumor cells in vitro.

On the other hand, qPCR analysis showed the MDA-MB-231 tumor stroma to express muCCL5 (Figure 10A), a monocyte chemotactic chemokine. Stromal CCL5 expression was significantly upregulated in CXCL4 ${ }^{47-70}$-treated mice $(\mathrm{p}=0.020, \mathrm{n}=7)$. MDAMB-231 cells themselves were also observed to express CCL5 in vitro, particularly upon TNF- $\alpha$ stimulation (data not shown). CCL5 has previously been described to multimerize with intact CXCL4 [34]. Therefore, binding assays were performed to corroborate a possible interaction. We found that both CXCL4 $4^{47-70}$ and CXCL4L1 $1^{47-70}$ directly and equally well interacted with CCL5 (Figure 10B). Considering previous reports of CCL5/CXCL4 multimers synergistically increasing monocyte attraction [34], we verified whether the interaction between the peptides and CCL5 could contribute to an enhanced monocyte influx into the tumors. It was demonstrated that adding CXCL4 ${ }^{47-70}$ or CXCL4L $1^{47-70}$ to CCL5 in the lower compartment of multiscreen chemotaxis chambers enhanced transendothelial migration of monocytic cells. Similar to the intact chemokines, CXCL4 ${ }^{47-70}$ more efficiently stimulated monocytic cell chemotaxis compared to CXCL4L1 ${ }^{47-70}$ (Figure 10C). These findings could explain the observed changes in the tumoral leukocyte population following peptide treatment.

\section{DISCUSSION}

The chemokines CXCL4 and CXCL4L1 have both been attributed anti-tumoral activity as a result of angiostatic action, blockade of lymphatic vessel formation and the attraction of anti-tumoral lymphocytes [21, 23, $35,36]$. CXCL4L1 is considered to be a more powerful angiostatic and anti-tumoral agent than its homologue CXCL4, despite their striking 96\% sequence identity $[15,35]$. This functional difference has been linked to a single amino acid replacement, causing CXCL4L1 to adapt a unique carboxy-terminal 3D-structure with decreased affinity for GAGs [13]. However, the causal link remains puzzling, considering that CXCL4's capacity 


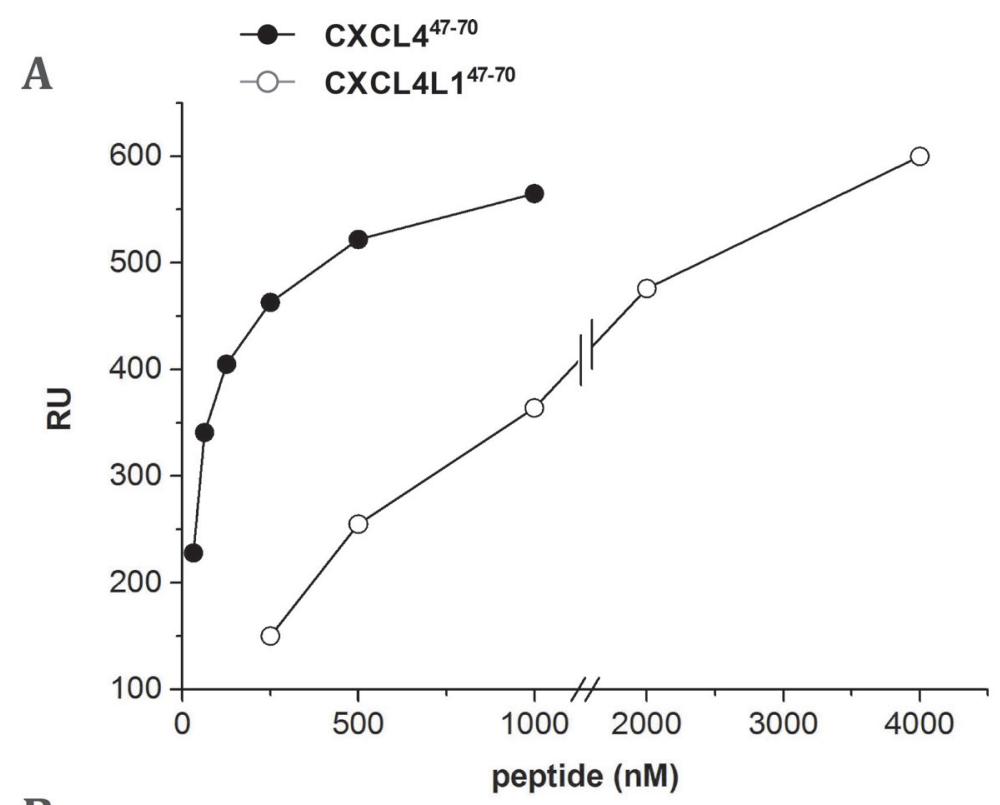

B

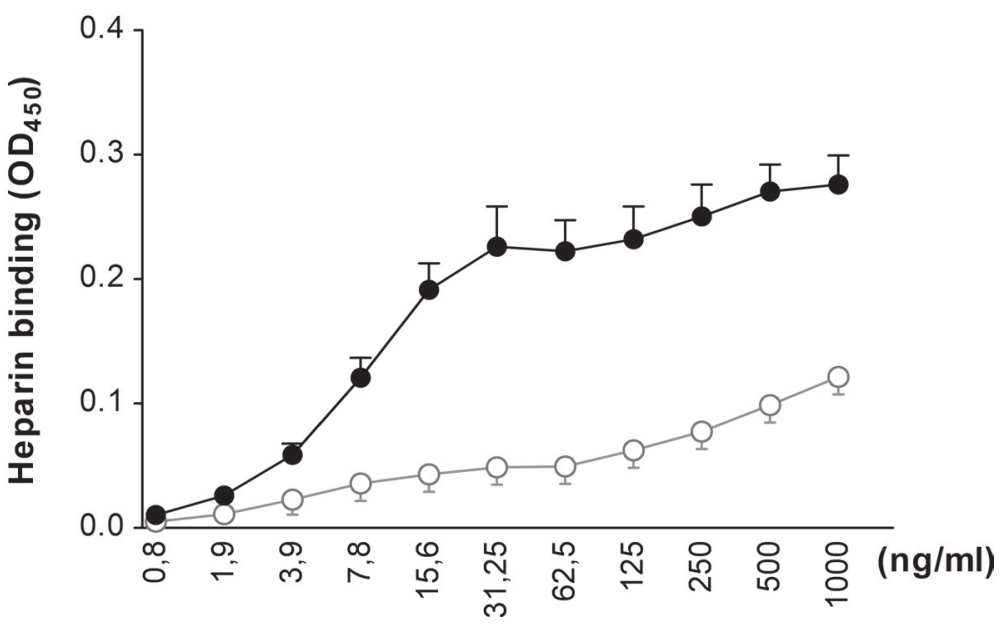

Figure 8: Interaction of CXCL4 $4^{47-70}$ and CXCL4L1 ${ }^{47-70}$ peptides with immobilized heparin. Binding of the indicated concentrations of CXCL4 ${ }^{47-70}$ and CXCL4L1 ${ }^{47-70}$ to heparin was analyzed through measurement of peptide binding to sensorchipimmobilized heparin (A). Data are expressed as Resonance Units (RU). Alternatively, GAG binding was evaluated by immobilizing low molecular weight heparin on EpranEx plates (B). Amino-terminally biotinylated CXCL4 ${ }^{47-70}$ and CXCL4L1 ${ }^{47-70}$ interacting with the heparin-coated plate were detected with peroxidase-conjugated streptavidin. Results are expressed as average optical densities ( \pm s.e.m.) measured at $450 \mathrm{~nm}\left(\mathrm{OD}_{450}\right)$. A: one representative experiment out of three; $\mathrm{B}: \mathrm{n}=3$

Table 1: Binding parameters of the interaction of CXCL4 $4^{47-70}$ and $C X C L 4 L 11^{47-70}$ peptides with heparin immobilized on a BIAcore sensorchip

\begin{tabular}{|c|c|c|c|c|}
\hline Peptide & $\begin{array}{l}\text { Association rate }\left(K_{o n}\right) \\
(1 / \mathbf{M s})\end{array}$ & $\begin{array}{l}\text { Dissociation rate } \\
\left(K_{o f f}\right)(1 / \mathbf{s})\end{array}$ & $K_{d}\left(K_{o f f} / K_{o n}\right)(\mathbf{M})$ & $K_{d}(\mathbf{M})$ at equilibrium \\
\hline CXCL4 $47-70$ & $6.7 \times 10^{5}$ & $1.1 \times 10^{-2}$ & $1.6 \times 10^{-8}$ & $7.2 \times 10^{-8}$ \\
\hline CXCL4L147-70 & $5.2 \times 10^{4}$ & $5.3 \times 10^{-2}$ & $1.0 \times 10^{-6}$ & $1.2 \times 10^{-6}$ \\
\hline
\end{tabular}

$K_{o n}$ and $K_{o f f}$ of peptide/heparin interactions are shown. The $K_{d}$ value was derived from the $K_{\text {off }} / K_{\text {on }}$ ratio as well as by Scatchard plot analysis of the equilibrium binding data. 


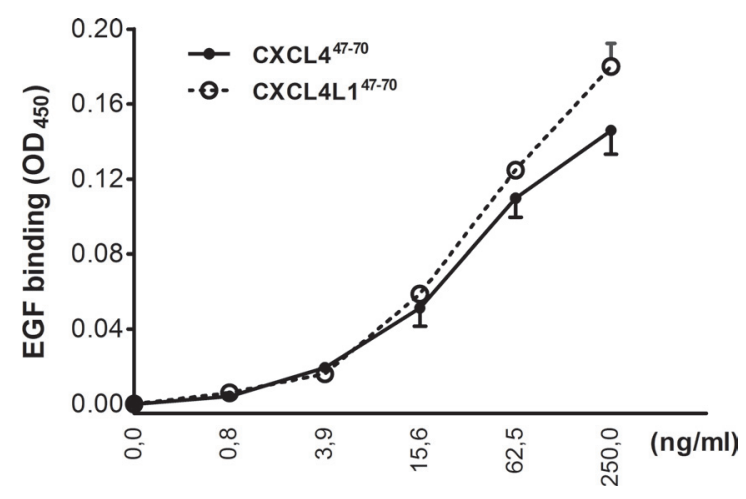

Figure 9: Interaction of CXCL4 $4^{47-70}$ and CXCL4L1 ${ }^{47-70}$ with EGF. In order to evaluate interaction of CXCL4 ${ }^{47-70}$ and CXCL4L1 $1^{47-70}$ with EGF, binding of amino-terminally biotinylated CXCL4 $4^{47-70}$ or CXCL4L1 ${ }^{47-70}$ to EGF-coated plates was detected with peroxidase-conjugated streptavidin. Results are expressed as average optical densities $( \pm$ s.e.m. $)$ measured at $450 \mathrm{~nm}\left(\mathrm{OD}_{450}\right) \cdot \mathrm{n}=3$

to bind GAGs, via a carboxy-terminal motif, has actually long been thought to be the main contributor to its angiostatic potential [18]. Moreover, carboxy-terminal peptides restricted to the last 24 amino acids of either CXCL4 (CXCL447-70) or CXCL4L1 (CXCL4L1 17-70) have been described to retain their anti-angiogenic and antitumoral properties $[18,19]$. In an attempt to understand the working mechanism of both chemokines and thereby their future possible therapeutic applicability, we studied the angiostatic and anti-tumoral potential of these peptides more in depth. Interestingly, in the here studied MDAMB-231 breast cancer model, CXCL4L1 $1^{47-70}$ loses its relative potency over CXCL4 ${ }^{47-70}$. This is in contrast with a previous study by our group demonstrating beneficial effects of CXCL4L1 $1^{47-70}$, but not of CXCL4 $4^{47-70}$, in the treatment of B16 melanoma. The anti-tumoral activity of CXCL4L $1{ }^{47-70}$ was ascribed to inhibition of angiogenesis and induction of apoptosis within the B16 melanoma tumor tissue [19]. In the MDA-MB-231 model, the antitumoral activity of the peptides probably depends more on the establishment of an anti-tumoral immune response and direct inhibition of tumor cell proliferation.

To reveal the molecular mechanisms involved we explored different possibilities, the first being direct molecular interaction between CXCL4 $4^{47-70}$ or CXCL4L1 ${ }^{47-70}$ and other cytokines (e.g. CCL5 and EGF). This heteromultimerization could change the receptor-activating properties of the cytokines. Second, binding to GAGs was assessed, which might affect kinetics of in vivo availability. GAG binding could also cause displacement of other cytokines from GAGs (decreasing cytokine receptor activation) or, on the contrary, could improve GAG interaction (enhancing cytokine activity). Finally, in addition to receptorindependent activities and GAG binding, a cellular receptor might be involved.

Concerning direct cytokine ligand interactions, both positive and negative interactions have been described for intact CXCL4 [33, 34, 37, 38] and its carboxy-terminal peptide [39]. CXCL4 has been demonstrated to counteract angiogenic VEGF and FGF2, by direct molecular interaction (heterodimerization) or GAG-displacement [37, 38]. In contrast, intact CXCL4 enhances monocyte chemotactic activity of CCL5 through heteromultimerization [34]. In this study we chose two cytokines important in our breast cancer model and verified interaction with CXCL4 $4^{47-70}$ and CXCL4L1 ${ }^{47-70}$ : EGF as growth factor for the tumor cells and CCL5 as attractant of monocytes/macrophages. Both peptides bound with similar efficiency to immobilized EGF or CCL5. Furthermore, addition of CXCL4 $4^{47-70}$ or CXCL4L $1^{47-70}$ to CCL5 in a monocyte transendothelial migration assay increased monocyte chemotactic activity. On the other hand, we could not demonstrate binding or activation of CXCR3 by CXCL4 $4^{47-70}$ or CXCL4L1 ${ }^{47-70}$ suggesting that either no cellular receptor or a still unidentified receptor is activated. Alternatively, because the 47-70 carboxy-terminal domain contains the main GAG interaction site of CXCL4, we assessed heparin affinity of both peptides. We confirmed already published findings that CXCL4 $4^{47-70}$ still interacts with heparin [18]. The heparin affinity of CXCL4 $4^{47-70}$ was higher than that of CXCL4L1 $1^{47-70}$. We therefore expect CXCL4 ${ }^{47-70}$ to be retained longer at the site of injection and to exert its anti-tumoral activities over a longer time period. Our findings could explain the apparent difference between almost equal potency of the peptides in vitro (Figures 1-4) compared to more outspoken antitumoral activity for CXCL4 $4^{47-70}$ in this in vivo breast cancer model.

Perception of the role of the immune system in tumor development has changed over time. Tumor inflammation is indeed the seventh hallmark of malignant disease, but the sizeable myeloid population present has been mostly observed to take on a tumor-promoting role rather than exert its protective, phagocytic and cytotoxic 
A

mu CCL5

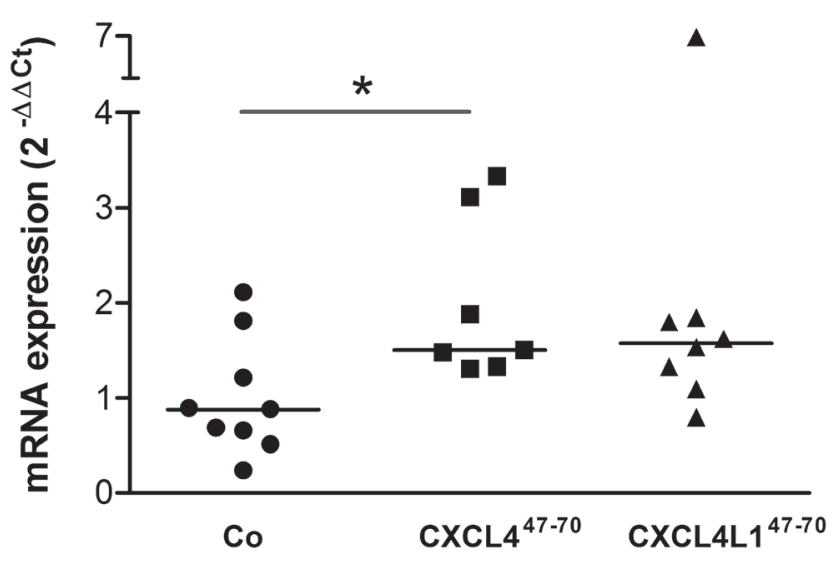

B

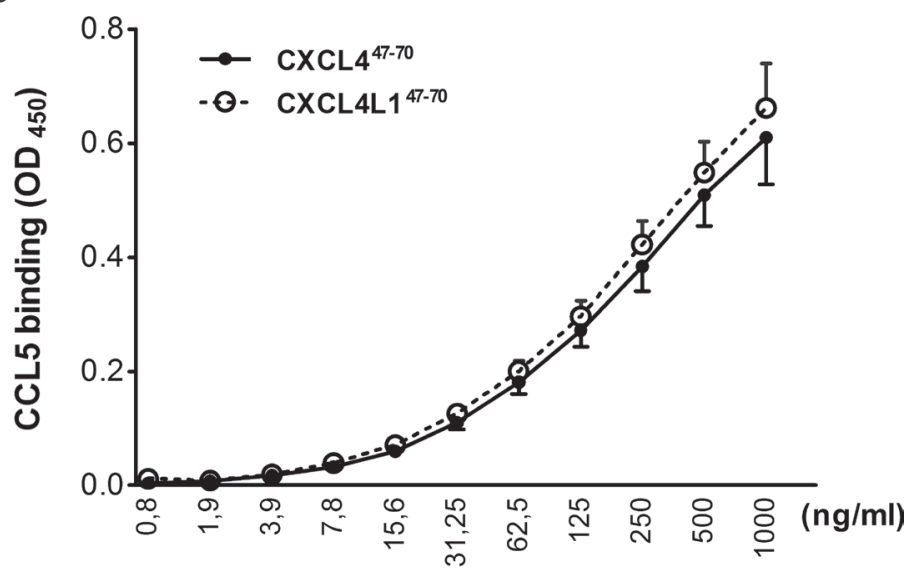

C



Figure 10: Interaction of CXCL4 ${ }^{47-70}$ and CXCL4L1 ${ }^{47-70}$ with CCL5. Changes in the expression of murine (mu) CCL5 within the tumor microenvironment were evaluated in vehicle (CO)-, CXCL447-70 - and CXCL4L1 ${ }^{47-70}$-treated MDA-MB-231 tumors by qPCR (A). Fold changes in mRNA levels were calculated according the $2^{-\Delta \Delta C T}$ method. The median value per group is indicated by a horizontal bar. In order to further evaluate a possible interaction between CCL5 and the administered peptides, binding of biotinylated CXCL4 ${ }^{47-70}$ or CXCL4L1 ${ }^{47-70}$ to human CCL5-coated plates was quantified (B), whereas functional synergy was investigated by evaluating chemotaxis of monocytic cells (C). THP-1 cells were stimulated with CCL5 $(20 \mathrm{ng} / \mathrm{ml})$, intact CXCL4 (500 ng/ml), CXCL4 ${ }^{47-70}$, CXCL4L1 ${ }^{47-70}$ (both 1000 to $5000 \mathrm{ng} / \mathrm{ml}$ ) or combinations thereof in a multiscreen chemotaxis assay. A: $\mathrm{n}=7$ to $9 ; \mathrm{B}: \mathrm{n}=3 ; \mathrm{C}: \mathrm{n}=3$ to $4 ;{ }^{*} \mathrm{p}<0.05$ 
function [40-42]. This shift could be attributed to the phagocytes' versatility and their ability to adopt distinct phenotypes influenced by locally produced factors [43]. Rather than depleting the tumoral myeloid cell population, it could be beneficial to tackle its polarization and to have its pro-inflammatory actions complement anti-tumoral treatment. Therapeutic reversion of the tumor-associated leukocyte polarization could alter their impact on tumor progression, favoring anti-tumor immunity. Previously, CXCL4 has been reported to promote monocyte survival and macrophage activation [44]. This fits with the observed upregulation of macrophage markers in CXCL4 ${ }^{47-70}$-treated tumors. The carboxy-terminal CXCL4 peptide could potentially maintain its effect on monocyte survival and activation, thereby leading to an expanding intratumoral macrophage population. As a single stimulus, CXCL $4^{47-70}$ has been stated not to stimulate monocytic THP-1 migration [19]. Interestingly however, as already discussed, we revealed CXCL4 $4^{47-70}$ and CXCL4L1 ${ }^{47-70}$ to be able to multimerize with the monocyte chemoattractant CCL5, consequently enhancing migration of monocytic cells in vitro. Especially because the in vivo angiostatic effects were less prominent in this study, our results suggest that the CXCL4 ${ }^{47-70}$-specific immunological effect might be a driving force behind its in vivo induced tumor growth retardation.

We did also confirm the conservation of angiostatic activity for both carboxy-terminal platelet factor peptides in vitro $[17,19]$. Where our previous study has focused on the inhibitory effect of the peptides on endothelial cell migration, we now report anti-proliferative effects of CXCL4 $4^{47-70}$ and CXCL4L1 $1^{47-70}$ on both blood and lymphatic endothelial cells. Broadening the spectrum of activity to include blockade of lymphangiogenesis offers an interesting new therapeutic perspective as the lymphatic vasculature has been implied to be an escape route for metastatic tumor cells [21].

To date, anti-angiogenic therapy has not delivered on expectations in cancer research. Where anti-angiogenesis falls short, the immune system seems to play a critical role. Alternative avenues need to be explored. Here, we illustrate the anti-proliferative, angiostatic, inflammatory and overall anti-tumoral actions of carboxy-terminal peptides CXCL4 $4^{47-70}$ and CXCL4L1 $1^{47-70}$, which are in line with the effects of the original full-length mature proteins. However, the sum of their actions and eventual impact in vivo appear to be tumor model-dependent. Such a tumordependent therapy responsiveness to treatment would have important implications towards future therapeutic use of CXCL4, CXCL4L1 and derived peptides. In conclusion, this study illustrates, angiostatic chemokines such as CXCL4, CXCL4L1 and their derived peptides could fit the profile of multifunctional new anti-cancer therapeutics perfectly.

\section{METHODS}

\section{Synthesis and purification of $\mathrm{CXCL4}^{47-70}$ and CXCL4L1 ${ }^{47-70}$}

The human carboxy-terminally derived peptides of the chemokines CXCL4 and CXCL4L1, namely $\mathrm{CXCL}^{47-70}$ and CXCL4L1 ${ }^{47-70}$, were synthesized by fluorenyl methoxycarbonyl (Fmoc) chemistry on a P11 peptide synthesizer (Activotec, Cambridge, UK) and purified by reversed phase chromatography as previously described [19]. Side-specific coupling of biotin to the $\mathrm{N}$-terminus of the peptides was performed on the peptide synthesizer by activating and coupling biotin-ONp (Biotin p-nitrophenyl ester, Novabiochem, Darmstadt, Germany) on the Fmoc-deprotected N-terminus with the same program that was used for coupling the individual Fmoc-amino acids. This results in exactly one biotin group attached to the N-terminus of the peptide without modification of the side chains of lysine residues. Peptide purity, concentration and molecular mass were verified by ion trap mass spectrometry (Bruker, Bremen, Germany).

\section{Cell cultures}

Preliminary tests were performed on fetal bovine aortic endothelial GM7373 cells [45], obtained from the N.I.G.M.S. Human Genetic Mutant Cell Repository (Institute for Medical Research, Camden, NJ) and grown in Eagle's MEM containing 10\% fetal calf serum (FCS). HMVEC (Cell Systems, Kirkland, WA) and HLEC (Lonza, Verviers, Belgium) were grown in endothelial basal medium-2 (EBM-2) enriched with endothelial growth medium-2 MV Bulletkit (Lonza), following the manufacturer's instructions. In order to investigate the anti-tumoral effects of the chemokine-derived peptides, the EGF-dependent tumor cell line MDA-MB-231 was purchased from ATCC (Manassas, VA) and cultured in DMEM (Lonza) with 10\% FCS. Human acute monocytic leukemia cells (THP-1) were cultured as previously described [46].

\section{Cell proliferation assays}

\section{MTT proliferation assay}

First, HMVEC and HLEC were seeded at $5 \times 10^{3}$ cells/well in EBM-2 + 1\% FCS in a 96-well plate, whereas MDA-MB-231 were starved of growth factors overnight by replacing their growth medium with DMEM (serumfree) prior to seeding the tumor cells at $15 \times 10^{2}$ cells/ well in DMEM $+1 \%$ FCS. As for the rest of the assay, the same protocol applies to all cells. Once adherent, cells were incubated with different concentrations of the 
peptides CXCL4 $4^{47-70}$ and CXCL4L1 $1^{47-70}$ as single stimuli or in combination with recombinant human EGF (3 ng/ml; R\&D Systems, Minneapolis, $\mathrm{MN}$ ) at $37^{\circ} \mathrm{C} / 5 \% \mathrm{CO}_{2}$. All conditions were tested in triplicate or quadruplicate. After 3 to 4 days, stimulation medium was removed and a sterile MTT solution was added $[0.04 \mathrm{~g} / 100 \mathrm{ml}$ thiazolyl blue (Sigma-Aldrich, St. Louis, MO) in 20\% PBS/ $80 \%$ RPMI without phenol red (Lonza)] for 3 to 4 hours. The formed formasan crystals were dissolved by replacing the MTT solution with acidic propanol $(0.04 \mathrm{M} \mathrm{HCl}, 0.1 \%$ $(\mathrm{v} / \mathrm{v})$ Nondet P-40 in absolute isopropanol) and shaking the plate, shielded from light, for 10 minutes. Optical density (OD) was determined at $570 \mathrm{~nm}$ and $630 \mathrm{~nm}$. The obtained ODs were processed to proliferation indexes (PI), expressed relative to appropriate buffer controls, i.e. $\Delta \mathrm{OD} 570-630_{\mathrm{X}}$ over $\Delta \mathrm{OD} 570-630_{\mathrm{CO}}$

\section{GM7373 proliferation assay}

Cell proliferation assays on GM7373 cells were performed as described [47]. Briefly, subconfluent cultures of GM7373 cells were seeded in 96-well dishes at $65 \times 10^{3}$ cells $/ \mathrm{cm}^{2}$. After $16 \mathrm{~h}$, cells were incubated in triplicate in fresh medium containing $0.4 \%$ FCS plus FGF1 (30 ng/ml), FGF2 (10 ng/ml), FGF8 (30 ng/ml), EGF (10 ng/ml), VEGF $(30 \mathrm{ng} / \mathrm{ml}), 12-$ O-tetradecanoyl phorbol 13 -acetate (TPA, $10 \mathrm{ng} / \mathrm{ml}$ ) or $10 \% \mathrm{FCS}$ in the absence or in the presence of $400 \mathrm{ng} / \mathrm{ml}$ of CXCL4 ${ }^{47-70}$ or CXCL4L $1^{47-70}$. After $24 \mathrm{~h}$, cells were trypsinized and counted in a Bürker chamber. Data were expressed as percentages of cell proliferation measured in the presence of the mitogenic stimulus alone.

\section{Transendothelial multiscreen chemotaxis assay}

Monocyte chemotaxis assays were performed on $5 \mu \mathrm{m}$ hydrophilic polycarbonate multiscreen-MIC plates (Millipore) using the human acute monocytic leukemia cells (THP-1). To promote efficient synergy between CCL5 on one hand and CXCL4, CXCL4 ${ }^{47-70}$ or CXCL4L $1^{47-70}$ on the other hand, the upper compartment of these plates was coated with a HMVEC monolayer. HMVEC were seeded on a $0.1 \%$ gelatin layer 24 hours prior to the chemotaxis assay. The following day, dilutions of recombinant human CCL5 (PeproTech, Rocky Hill, CT), natural human CXCL4 (isolated from stimulated platelets as previously described) [15], recombinant human CXCL4L1 (isolated from baculovirus-infected Sf9 cells as previously described) [23], synthetic CXCL4 ${ }^{47-70}$, synthetic CXCL4L1 ${ }^{47-70}$ (both produced as described above), or combinations thereof were added to the lower compartment of the plate, in a volume of $150 \mu 1$. After removal of the HMVEC medium, $0.35 \times 10^{6}$ THP-1 cells were added to the upper wells, resuspended in phenol red-free RPMI + $0.1 \mathrm{~g} / 100 \mathrm{ml}$ BSA (endotoxin-free BSA; Sigma CatN $^{\circ}$ A8806) after centrifugation of the cells at $200 \mathrm{~g}$ for $10 \mathrm{~min}$. Plates were incubated at $37^{\circ} \mathrm{C}$ for 3 to 5 hours before quantifying the amount of cells that migrated towards the chemokine concentrations. For that purpose, we used the ATPlite kit (PerkinElmer, Waltham, MA) allowing quantitative luminescent detection of ATP, which is representative of THP-1 cell counts in the lower wells. This reaction was performed in a view white 96-well plate (PerkinElmer). A chemotactic index (CI) was calculated, defined as the ratio of luminescence after chemokine treatment and luminescence after control treatment.

\section{Intracellular p21 signaling assay}

Signaling assays [23] were slightly adapted to the signaling molecules of interest in this study. HMVEC were stimulated with EGF (20 ng/ml) as a single stimulus or in combination with the peptides $\mathrm{CXCL}^{47-70}$ and CXCL4L1 ${ }^{47-70}(0.3$ to $10 \mu \mathrm{g} / \mathrm{ml})$ in order to evaluate their impact on the cell cyclearresting p21. After 15 hours, the cells were washed three times with ice-cold PBS to stop the stimulation and lysis buffer [1 mM EDTA, 0.5\% (v/v) Triton-X, $10 \mathrm{mM} \mathrm{NaF}, 150 \mathrm{mM} \mathrm{NaCl}, 1 \mathrm{mM}$ DTT in PBS; $\mathrm{pH}$ 7.2-7.4] supplemented with a protease inhibitor cocktail (Sigma) was added. Cell residue was removed from the collected lysates by centrifugation $\left(4^{\circ} \mathrm{C}\right.$, $10 \mathrm{~min}, 1666 \mathrm{~g}$ ). Lastly, the intracellular p21 content was determined by DuoSet ${ }^{\circledR}$ IC ELISA (cat n ${ }^{\circ}$ DYC 1047, R\&D Systems) while, in parallel, total protein content was measured in a bicinchoninic acid (BCA) protein assay (Pierce, Rockford, IL).

\section{In vivo tumor experiment}

SCID mice were bred in specific-pathogen-free conditions in the Experimental Animal Breeding Facility of the University of Leuven (KU Leuven) and fed sterilized food and water. All animal experiments were conducted in agreement with the Ethical Committee for Animal Care and Use of the KU Leuven and executed under license number LA1210243. 7- to 10-week-old SCID mice were used throughout the experiments. MDA-MB-231 cells in $\log$ growth phase $\left(6 \times 10^{6}\right.$ cells resuspended in $200 \mu \mathrm{l}$ of PBS) were injected subcutaneously (s.c.) on day 0 in the right dorsal flank. Animals were treated by intratumoral injection with control, $2.5 \mu \mathrm{g}$ synthetic human CXCL4 ${ }^{47-70}$ peptide or synthetic human CXCL4L1 ${ }^{47-70}$ peptide three times a week starting from day 3. The external tumor volume was measured with calipers thrice a week and calculated using the formula $\left(4 \pi \mathrm{ab}^{2}\right) / 3$ in which $\mathrm{a}$ and $\mathrm{b}$ are the largest and smallest radius, respectively. On day 27 or 28 , mice were sacrificed and tumors were resected. The exact tumor volume of the resected tumor, based on three measured radii ( $a, b$ and $c)$, was calculated by the 
formula $(4 \pi \mathrm{abc}) / 3$. A portion of the tumors was stored at $-70^{\circ} \mathrm{C}$ for generation of mRNA extracts and another part was processed for flow cytometry.

\section{Flow cytometric analysis of $\mathrm{F} 4 / 80^{+}$cells}

For flow cytometry, single cell suspensions were prepared from tumor biopsies using a MACS dissociator (Myltenyi Biotec, Bergisch Gladbach, Germany) and a mixture of collagenase A and dispase. Remaining cell clumps were removed by passing the cell suspension through a nylon cell strainer (70 $\mu \mathrm{m}$ mesh). Remaining red blood cells were lysed in ACK lysis buffer (0.15 $\mathrm{M} \mathrm{NH}_{4} \mathrm{Cl}, 0.1 \mathrm{mM} \mathrm{Na} \mathrm{EDTA}_{2} 10 \mathrm{mM} \mathrm{KHCO}$; $\mathrm{pH}=7.2$ ). Subsequently monocytes were identified by flow cytometry using specific antibodies, namely rat antimouse F4/80-PE antibody (eBiosciences, San Diego, CA).

\section{Gene expression studies}

The RNeasy Mini Kit (QIAGEN, Venlo, the Netherlands) was used for tumor mRNA extraction. The extracted mRNA was then converted to cDNA making use of the High Capacity cDNA Reverse Transcription Kit (Applied Biosystems, Foster City, CA). Quantitative polymerase chain reactions (qPCR) based on the TaqMan principle were conducted to compare gene expression between samples. Primers and probes (Table 2; Integrated DNA Technologies, Haasrode, Belgium), were diluted to the prescribed working concentrations in RNase-free water and added to the reaction mix in a MicroAmp ${ }^{\circledR}$ fast optical 96-well reaction plate (Applied Biosystems), together with $50 \mathrm{ng}$ sample cDNA per reaction. The actual thermocycler program consisted of 2 minutes on $50{ }^{\circ} \mathrm{C}, 10$ minutes on $95^{\circ} \mathrm{C}$ and 40 cycles of 15 seconds on $95^{\circ} \mathrm{C}$ followed by 1 minute on $60^{\circ} \mathrm{C}$. Analysis of the obtained $\mathrm{C}_{\mathrm{T}}$ was based on the $2^{-\triangle \Delta C \mathrm{~T}}$ method, opting for $18 \mathrm{~S}$ ribosomal 1 RNA as an internal control [48].

\section{SPR equipment and reagents}

SPR measurements were performed on a BIAcore X100 instrument (GE-Healthcare, Milwaukee, WI). Research-grade SA sensorchip was used. For the study of the interaction of heparin with CXCL4 $^{47-70}$ and CXCL4L1 ${ }^{47-70}$, heparin was immobilized to a BIAcore

Table 2: Primer and probe sequences for qPCR assays

\begin{tabular}{|c|c|c|}
\hline Gene & Primers $\left(5^{\prime} \rightarrow 3^{\prime}\right)$ & Probe $\left(5^{\prime} \rightarrow 3^{\prime}\right)$ \\
\hline $\mathrm{F} 4 / 80$ & $\begin{array}{l}\text { GGAAGTGGATGGCATAGATGA } \\
\text { ATTCACTGTCTGCTCAACCG }\end{array}$ & $\begin{array}{l}\text { /HEX/AGTCTGGGA/ZEN/ } \\
\text { ATGGGAGCTAAGGTCA/3IABkFQ/ }\end{array}$ \\
\hline IFN- $\gamma$ & $\begin{array}{l}\text { TCCACATCTATGCCACTTGAG } \\
\text { CTGAGACAATGAACGCTACACA }\end{array}$ & \begin{tabular}{|l} 
/HEX/TCTTGGCTT/ZEN/ \\
TGCAGCTCTTCCTCA/3IABkFQ/
\end{tabular} \\
\hline TGM2 & $\begin{array}{l}\text { GGTTCATATCCAAGAGCATCAGG } \\
\text { GTCAAGTTCATCAAGAGTGTGC }\end{array}$ & $\begin{array}{l}\text { /FAM/TTCCATCCT/ZEN/ } \\
\text { CGAACTGCCCAAAGT/3IABkFQ/ }\end{array}$ \\
\hline CD204 & $\begin{array}{l}\text { CACAAGGAGGTAGAGAGCAATG } \\
\text { GCACGTTCAATGACAGCATC } \\
\end{array}$ & $\begin{array}{l}\text { /FAM/TCACAGCAC/ZEN/ } \\
\text { TAAAAATGGCCCCTCC/3IABkFQ/ }\end{array}$ \\
\hline IL-12 & $\begin{array}{l}\text { TCCAGTCCACCTCTACAACA } \\
\text { TGTCCTCAGAAGCTAACCATC }\end{array}$ & $\begin{array}{l}\text { /FAM/ACGTCTTTC/ZEN/ } \\
\text { TCCAGCTCCCACATG/3IABkFQ/ }\end{array}$ \\
\hline NOS2 & $\begin{array}{l}\text { CACTTCTGCTCCAAATCCAAC } \\
\text { GACTGAGCTGTTAGAGACACTT }\end{array}$ & $\begin{array}{l}\text { /HEX/TGAACAAGA/ZEN/ } \\
\text { CCCAAGCGTGAGGAG/3IABkFQ/ }\end{array}$ \\
\hline CD11c & $\begin{array}{l}\text { CTACCCGAGCCATCAATCAG } \\
\text { GCTCTGCTTTCTACTGAGTTCA }\end{array}$ & $\begin{array}{l}\text { /HEX/AGCCAGAAC/ZEN/ } \\
\text { TTCCCAACTGCACA/3IABkFQ/ }\end{array}$ \\
\hline CCL5 (mu) & $\begin{array}{l}\text { CCTCTATCCTAGCTCATCTCCA } \\
\text { GCTCCAATCTTGCAGTCGT }\end{array}$ & $\begin{array}{l}\text { /HEX/TCTTCTCTG/ZEN/ } \\
\text { GGTTGGCACACACTT/3IABkFQ/ }\end{array}$ \\
\hline CCL5* (hu) & $\begin{array}{l}\text { TGCCACTGGTGTAGAAATACTC } \\
\text { GCTGTCATCCTCATTGCTACT } \\
\end{array}$ & $\begin{array}{l}\text { /FAM/ATCTGCCTC/ZEN/ } \\
\text { CCCATATTCCTCGGA/3IABkFQ/ }\end{array}$ \\
\hline $18 \mathrm{~S}$ & $\begin{array}{l}\text { ATCGCTCCACCAACTAAGAAC } \\
\text { ACGGACAGGATTGACAGATTG }\end{array}$ & $\begin{array}{l}\text { /FAM/ACCACCCAC/ZEN/ } \\
\text { GGAATCGAGAAAGAG/3IABkFQ/ }\end{array}$ \\
\hline
\end{tabular}

All primer/probe sets were supplied as PrimeTime qPCR assays by Integrated DNA Technologies (IDT)

* All assays were designed for murine (mu) gene products with the exception of this assay, designed to detect the human (hu) CCL5 cDNA. 
sensorchip. Briefly, 13600 Da unfractionated heparin was biotinylated at its reducing end and immobilized onto the SA streptavidin-coated sensorchip. These experimental conditions allowed the immobilization of 200 resonance units (RU) equal to $14.7 \mathrm{fmol} / \mathrm{mm}^{2}$ of heparin. A sensorchip coated with streptavidin alone was used as a reference and for blank subtraction. The peptides were dissolved in $10 \mathrm{mM}$ HEPES buffer $\mathrm{pH} 7.4$ containing $150 \mathrm{mM} \mathrm{NaCl}, 3 \mathrm{mM}$ EDTA, $0.05 \%$ surfactant P20 (HBS-EP+) and injected at different concentrations over the heparin or streptavidin surfaces for $2 \mathrm{~min}$ at a flow rate of $30 \mu \mathrm{l} / \mathrm{min}$ and then washed until dissociation was observed. After each run, the sensorchip was regenerated by injection of $\mathrm{HBS}-\mathrm{EP}+$ containing $2.0 \mathrm{M} \mathrm{NaCl}$.

\section{GAG binding and heterodimerization assays in 96-well plates}

GAG, EGF and CCL5 binding were quantified in 96-well plates following a similar protocol. GAG binding was evaluated by immobilizing low molecular weight heparin (Iduron, Manchester, UK) on EpranEx plates (BD Biosciences), whereas EGF as well as CCL5 recombinant human protein (R\&D Systems and PeproTech, respectively) was immobilized on high protein-binding ELISA plates (Corning life sciences, Tewksbury, MA). In brief, $25 \mu \mathrm{g} / \mathrm{ml} \mathrm{GAG}$ [diluted in assay buffer $100 \mathrm{mM}$ $\mathrm{NaCl}, 50 \mathrm{mM} \mathrm{NaAc}, \mathrm{pH} 7.2$, and 0.2\% (v/v) Tween-20], $2 \mu \mathrm{g} / \mathrm{ml} \mathrm{EGF}$ or $50 \mathrm{ng} / \mathrm{ml}$ CCL5 (both diluted in PBS), was coated overnight at room temperature on 96-well plates. Plates were washed three times with either assay buffer or $0.5 \%(\mathrm{v} / \mathrm{v})$ Tween 20 in PBS and blocked at $37^{\circ} \mathrm{C}$ with buffer enriched with either $0.2 \%(\mathrm{w} / \mathrm{v})$ gelatin (heparin binding assay) or $0.1 \%(\mathrm{w} / \mathrm{v})$ casein $(\mathrm{EGF}$ or CCL5 binding assay). Subsequently, a dilution curve of biotinylated CXCL4L1 $1^{47-70}$ and CXCL4 ${ }^{47-70}$ peptide was pipetted on the plate and incubated at $37{ }^{\circ} \mathrm{C}$ to allow interaction with heparin, EGF or CCL5. After washing, retained biotinylated peptide was detected by peroxidase-conjugated streptavidin. Peroxidase activity was quantified by measuring the conversion of 3,3',5,5'-tetramethylbenzidine (Sigma-Aldrich) at $450 \mathrm{~nm}$.

\section{Statistical analysis}

The Mann-Whitney test was used as a nonparametric test to compare data from two independent groups, performed with the use of Statistica 12. When comparing three or more independent groups, a Kruskal-Wallis test was performed firstly to allow subsequent pairwise comparison. Linear regression was performed and evaluated using GraphPad Prism 5 software. Correlations were confirmed by calculation of the Spearman r coefficient with Statistica 12. Given data represent an average \pm standard error of the mean (s.e.m.), unless stated otherwise. A $p$-value of less than
0.05 was considered to indicate a statistically significant difference. The number of independent experiments was indicated by $\mathrm{n}$.

\section{ACKNOWLEDGEMENTS}

The authors would like to thank Noëmie Pörtner, Isabelle Ronsse and Lotte Vanbrabant for excellent technical assistance. We also want to thank Prof. Dr. Sandra Liekens for critically reading the manuscript. This work was supported by grants from Ministero dell'Istruzione, Università e Ricerca (FIRB project RBAP11H2R9 2011) and Associazione Italiana per la Ricerca sul Cancro (AIRC grant $n^{\circ} 10396$ ), as well as by the Fund for Scientific Research of Flanders (FWOVlaanderen project G.0764.14 and G.0773.13), the Interuniversity Attraction Poles Programme initiated by the Belgian Science Policy Office (I.A.P. project P7/40) and the Concerted Research Actions of the Regional Government of Flanders (GOA13/014). The Hercules foundation of the Flemish government provided funding to purchase the LC-MS/MS equipment (AKUL/11/31).

\section{Ethical standards and conflict of interest}

Design and execution of all experiments are compliant with current legal requirements as stated by Belgian law. The authors also declare that they have no conflict of interest.

\section{REFERENCES}

1. Carmeliet P. Angiogenesis in health and disease. Nat Med. 2003; 9:653-660.

2. Folkman J. Tumor angiogenesis: therapeutic implications. N Engl J Med. 1971; 285:1182-1186.

3. Keeley EC, Mehrad B, Strieter RM. Chemokines as mediators of tumor angiogenesis and neovascularization. Exp Cell Res. 2011; 317:685-690.

4. Sharpe RJ, Byers HR, Scott CF, Bauer SI, Maione TE. Growth inhibition of murine melanoma and human colon carcinoma by recombinant human platelet factor 4 . J Natl Cancer Inst. 1990; 82:848-853.

5. Balkwill FR. The chemokine system and cancer. J Pathol. 2012; 226:148-157.

6. Vandercappellen J, Van Damme J, Struyf S. The role of the CXC chemokines platelet factor-4 (CXCL4/PF-4) and its variant (CXCL4L1/PF-4var) in inflammation, angiogenesis and cancer. Cytokine Growth Factor Rev. 2011; 22:1-18.

7. Sarvaiya PJ, Guo D, Ulasov I, Gabikian P, Lesniak MS. Chemokines in tumor progression and metastasis. Oncotarget. 2013; 4:2171-2185.

8. Rossi D, Zlotnik A. The biology of chemokines and their receptors. Annu Rev Immunol. 2000; 18:217-242. 
9. Bosisio D, Salvi V, Gagliostro V, Sozzani S. Angiogenic and antiangiogenic chemokines. Chem Immunol Allergy. 2014; 99:89-104.

10. Balestrieri ML, Balestrieri A, Mancini FP, Napoli C. Understanding the immunoangiostatic CXC chemokine network. Cardiovasc Res. 2008; 78:250-256.

11. Belperio JA, Keane MP, Arenberg DA, Addison CL, Ehlert JE, Burdick MD, Strieter RM. CXC chemokines in angiogenesis. J Leukoc Biol. 2000; 68:1-8.

12. Green CJ, Charles RS, Edwards BF, Johnson PH. Identification and characterization of PF4varl, a human gene variant of platelet factor 4. Mol Cell Biol. 1989; 9:1445-1451.

13. Kuo JH, Chen YP, Liu JS, Dubrac A, Quemener C, Prats H, Bikfalvi A, Wu WG, Sue SC. Alternative C-Terminal Helix Orientation Alters Chemokine Function: structure of the anti-angiogenic chemokine, CXCL4L1. J Biol Chem. 2013; 288:13522-13533.

14. Carlson J, Baxter SA, Dreau D, Nesmelova IV. The heterodimerization of platelet-derived chemokines. Biochim Biophys Acta. 2012; :S1570-S9639.

15. Struyf S, Burdick MD, Proost P, Van Damme J, Strieter RM. Platelets release CXCL4L1, a nonallelic variant of the chemokine platelet factor-4/CXCL4 and potent inhibitor of angiogenesis. Circ Res. 2004; 95:855-857.

16. Sarabi A, Kramp BK, Drechsler M, Hackeng TM, Soehnlein O, Weber C, Koenen RR, von Hundelshausen P. CXCL4L1 inhibits angiogenesis and induces undirected endothelial cell migration without affecting endothelial cell proliferation and monocyte recruitment. J Thromb Haemost. 2011; 9:209-219.

17. Hagedorn M, Zilberberg L, Lozano RM, Cuevas $\mathrm{P}$, Canron X, Redondo-Horcajo M, Gimenez-Gallego G, Bikfalvi A. A short peptide domain of platelet factor 4 blocks angiogenic key events induced by FGF-2. FASEB J. 2001; 15:550-552.

18. Maione TE, Gray GS, Petro J, Hunt AJ, Donner AL, Bauer SI, Carson HF, Sharpe RJ. Inhibition of angiogenesis by recombinant human platelet factor-4 and related peptides. Science. 1990; 247:77-79.

19. Vandercappellen J, Liekens S, Bronckaers A, Noppen S, Ronsse I, Dillen C, Belleri M, Mitola S, Proost P, Presta M, Struyf S, Van Damme J. The COOH-terminal peptide of platelet factor-4 variant (CXCL4L1/PF-4var47-70) strongly inhibits angiogenesis and suppresses B16 melanoma growth in vivo. Mol Cancer Res. 2010; 8:322-334.

20. Gentilini G, Kirschbaum NE, Augustine JA, Aster RH, Visentin GP. Inhibition of human umbilical vein endothelial cell proliferation by the CXC chemokine, platelet factor 4 (PF4), is associated with impaired downregulation of p21(Cip1/WAF1). Blood. 1999; 93:25-33.

21. Prats AC, Van den Berghe L, Rayssac A, Ainaoui N, Morfoisse F, Pujol F, Legonidec S, Bikfalvi A, Prats H, Pyronnet S, Garmy-Susini B. CXCL4L1-fibstatin cooperation inhibits tumor angiogenesis, lymphangiogenesis and metastasis. Microvasc Res. 2013; 89:25-33.

22. Shao XJ, Xie FM. Influence of angiogenesis inhibitors, endostatin and PF-4, on lymphangiogenesis. Lymphology. 2005; 38:1-8.

23. Van Raemdonck K, Gouwy M, Lepers SA, Van Damme J, Struyf S. CXCL4L1 and CXCL4 signaling in human lymphatic and microvascular endothelial cells and activated lymphocytes: involvement of mitogen-activated protein (MAP) kinases, Src and p70S6 kinase. Angiogenesis. 2014; 17:631-640.

24. Christiansen A, Detmar M. Lymphangiogenesis and cancer. Genes Cancer. 2011; 2:1146-1158.

25. Tatakis DN. Human platelet factor 4 is a direct inhibitor of human osteoblast-like osteosarcoma cell growth. Biochem Biophys Res Commun. 1992; 187:287-293.

26. Fan WH, Lu YL, Deng F, Ge XM, Liu S, Tang PH. EGFR antisense RNA blocks expression of the epidermal growth factor receptor and partially reverses the malignant phenotype of human breast cancer MDA-MB-231 cells. Cell Res. 1998; 8:63-71.

27. Subik K, Lee JF, Baxter L, Strzepek T, Costello D, Crowley P, Xing L, Hung MC, Bonfiglio T, Hicks DG, Tang P. The Expression Patterns of ER, PR, HER2, CK5/6, EGFR, Ki-67 and AR by Immunohistochemical Analysis in Breast Cancer Cell Lines. Breast Cancer (Auckl ). 2010; 4:35-41.

28. Gudkov AV, Gurova KV, Komarova EA. Inflammation and p53: A Tale of Two Stresses. Genes Cancer. 2011; 2:503-516.

29. Mantovani A, Sica A, Sozzani S, Allavena P, Vecchi A, Locati M. The chemokine system in diverse forms of macrophage activation and polarization. Trends Immunol. 2004; 25:677-686.

30. Martinez FO, Helming L, Milde R, Varin A, Melgert BN, Draijer C, Thomas B, Fabbri M, Crawshaw A, Ho LP, Ten Hacken NH, Cobos Jiménez V, Kootstra NA. Genetic programs expressed in resting and IL-4 alternatively activated mouse and human macrophages: similarities and differences. Blood. 2013; 121:e57-e69.

31. Dempe S, Lavie M, Struyf S, Bhat R, Verbeke H, Paschek S, Berghmans N, Geibig R, Rommelaere J, Van Damme J, Dinsart C. Antitumoral activity of parvovirusmediated IL-2 and MCP-3/CCL7 delivery into human pancreatic cancer: implication of leucocyte recruitment. Cancer Immunol Immunother. 2012; 61:2113-2123.

32. Bugatti A, Urbinati C, Ravelli C, De Clercq E, Liekens S, Rusnati M. Heparin-mimicking sulfonic acid polymers as multitarget inhibitors of human immunodeficiency virus type 1 Tat and gp120 proteins. Antimicrob Agents Chemother. 2007; 51:2337-2345.

33. Nesmelova IV, Sham Y, Gao J, Mayo KH. CXC and $\mathrm{CC}$ chemokines form mixed heterodimers: association free energies from molecular dynamics simulations 
and experimental correlations. J Biol Chem. 2008; 283:24155-24166.

34. von Hundelshausen P, Koenen RR, Sack M, Mause SF, Adriaens W, Proudfoot AE, Hackeng TM, Weber C. Heterophilic interactions of platelet factor 4 and RANTES promote monocyte arrest on endothelium. Blood. 2005; 105:924-930.

35. Struyf S, Burdick MD, Peeters E, Van den Broeck K, Dillen C, Proost P, Van Damme J, Strieter RM. Platelet factor-4 variant chemokine CXCL4L1 inhibits melanoma and lung carcinoma growth and metastasis by preventing angiogenesis. Cancer Res. 2007; 67:5940-5948.

36. Struyf S, Salogni L, Burdick MD, Vandercappellen J, Gouwy M, Noppen S, Proost P, Opdenakker G, Parmentier M, Gerard C, Sozzani S, Strieter RM, Van Damme J. Angiostatic and chemotactic activities of the CXC chemokine CXCL4L1 (platelet factor-4 variant) are mediated by CXCR3. Blood. 2011; 117:480-488.

37. Gengrinovitch S, Greenberg SM, Cohen T, Gitay-Goren H, Rockwell P, Maione TE, Levi BZ, Neufeld G. Platelet factor-4 inhibits the mitogenic activity of VEGF121 and VEGF165 using several concurrent mechanisms. J Biol Chem. 1995; 270:15059-15065.

38. Perollet C, Han ZC, Savona C, Caen JP, Bikfalvi A. Platelet factor 4 modulates fibroblast growth factor 2 (FGF-2) activity and inhibits FGF-2 dimerization. Blood. 1998; 91:3289-3299.

39. Jouan V, Canron X, Alemany M, Caen JP, Quentin G, Plouet J, Bikfalvi A. Inhibition of in vitro angiogenesis by platelet factor-4-derived peptides and mechanism of action. Blood. 1999; 94:984-993.

40. Sica A, Allavena P, Mantovani A. Cancer related inflammation: the macrophage connection. Cancer Lett. 2008; 267:204-215.
41. Colotta F, Allavena P, Sica A, Garlanda C, Mantovani A. Cancer-related inflammation, the seventh hallmark of cancer: links to genetic instability. Carcinogenesis. 2009; 30:1073-1081.

42. Piccard H, Muschel RJ, Opdenakker G. On the dual roles and polarized phenotypes of neutrophils in tumor development and progression. Crit Rev Oncol Hematol. 2012; 82:296-309.

43. Van Overmeire E, Laoui D, Keirsse J, Van Ginderachter JA, Sarukhan A. Mechanisms Driving Macrophage Diversity and Specialization in Distinct Tumor Microenvironments and Parallelisms with Other Tissues. Front Immunol. 2014; 5:127.

44. Scheuerer B, Ernst M, Durrbaum-Landmann I, Fleischer J, Grage-Griebenow E, Brandt E, Flad HD, Petersen F. The CXC-chemokine platelet factor 4 promotes monocyte survival and induces monocyte differentiation into macrophages. Blood. 2000; 95:1158-1166.

45. Grinspan JB, Mueller SN, Levine EM. Bovine endothelial cells transformed in vitro by benzo(a)pyrene. J Cell Physiol. 1983; 114:328-338.

46. Gouwy M, Struyf S, Noppen S, Schutyser E, Springael JY, Parmentier M, Proost P, Van Damme J. Synergy between coproduced $\mathrm{CC}$ and $\mathrm{CXC}$ chemokines in monocyte chemotaxis through receptor-mediated events. Mol Pharmacol. 2008; 74:485-495.

47. Presta M, Maier JA, Rusnati M, Ragnotti G. Basic fibroblast growth factor: production, mitogenic response, and post-receptor signal transduction in cultured normal and transformed fetal bovine aortic endothelial cells. J Cell Physiol. 1989; 141:517-526.

48. Livak KJ, Schmittgen TD. Analysis of relative gene expression data using real-time quantitative PCR and the 2(-Delta Delta C(T)) Method. Methods. 2001; 25:402-408. 